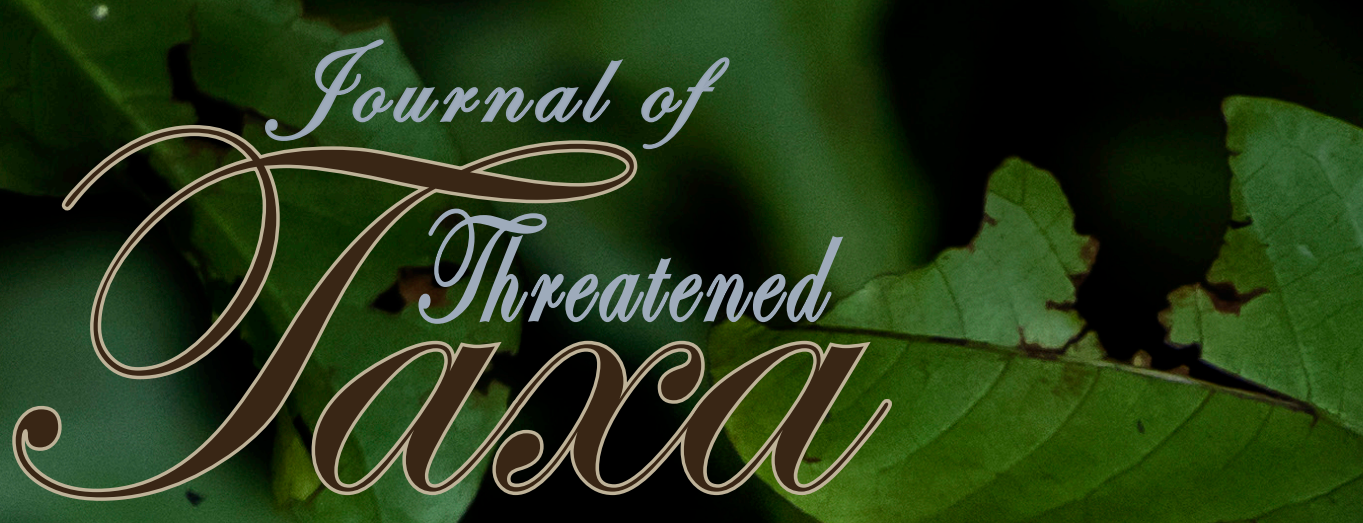

Building exidence for conservation glabally

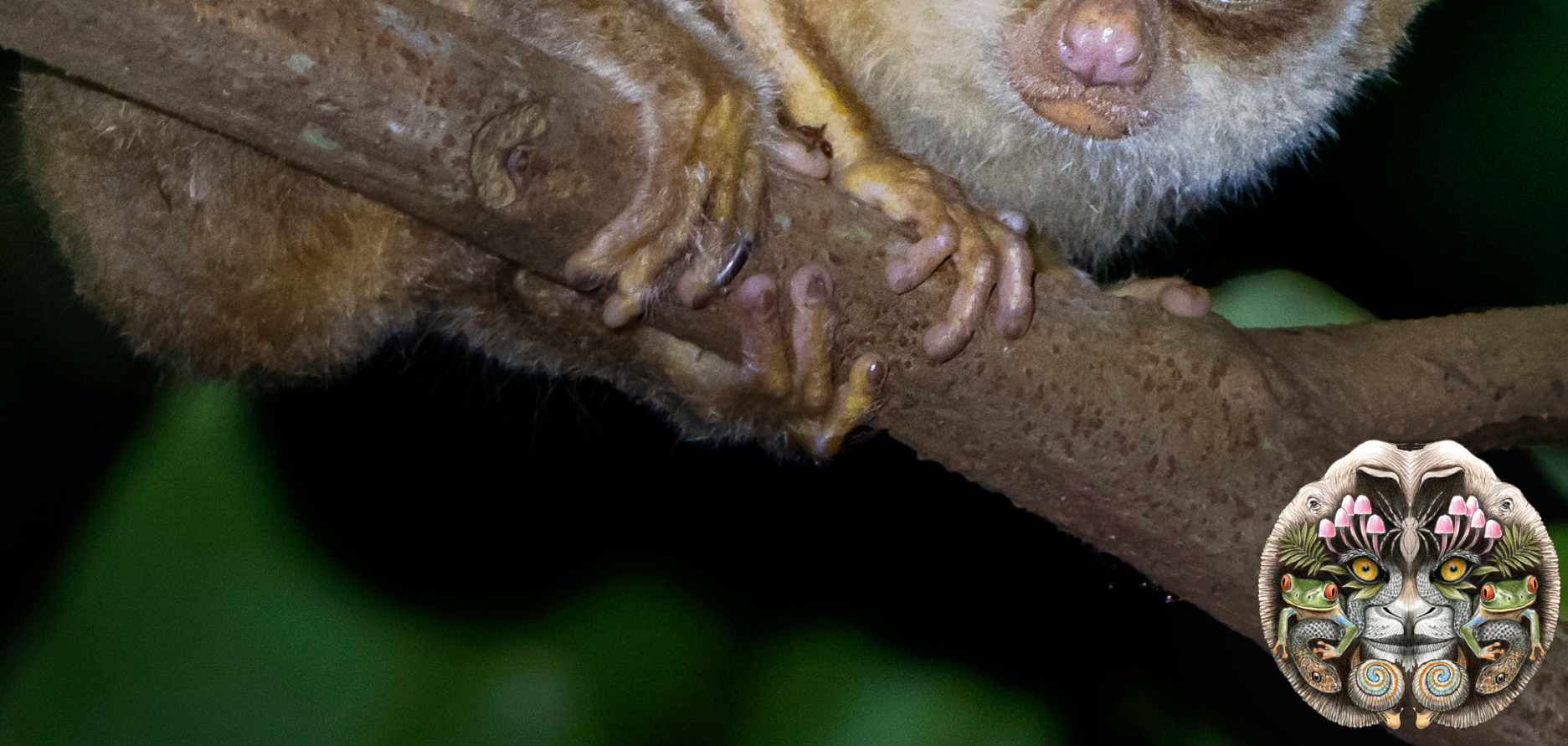

Open Access

$10.11609 /$ jott.2021.13.010.19431-19614 creven.threatenedtaxa.arg

26 September 2021 (Online \& Print) Val. 13 | Na. 11 | Pages: 19431-19674 


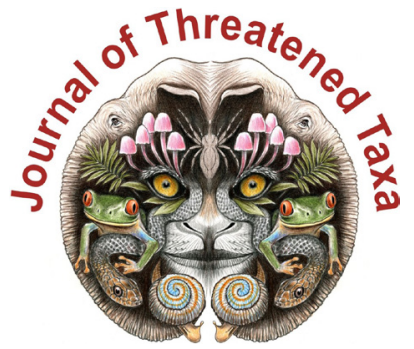

ISSN 0974-7907 (Online); ISSN $0974-7893$ (Print)

Publisher

Host

Wildlife Information Liaison Development Society

www.wild.zooreach.org

Zoo Outreach Organization www.zooreach.org

No. 12, Thiruvannamalai Nagar, Saravanampatti - Kalapatti Road, Saravanampatti, Coimbatore, Tamil Nadu 641035, India

Ph: +91 9385339863 | www.threatenedtaxa.org

Email: sanjay@threatenedtaxa.org

EDITORS

\section{Founder \& Chief Editor}

Dr. Sanjay Molur

Wildlife Information Liaison Development (WILD) Society \& Zoo Outreach Organization (ZOO)

12 Thiruvannamalai Nagar, Saravanampatti, Coimbatore, Tamil Nadu 641035, India

\section{Deputy Chief Edito}

Dr. Neelesh Dahanukar

Noida, Uttar Pradesh, India

\section{Managing Editor}

Mr. B. Ravichandran, WILD/ZOO, Coimbatore, India

\section{Associate Editors}

Dr. Mandar Paingankar, Government Science College Gadchiroli, Maharashtra 442605, India

Dr. Ulrike Streicher, Wildlife Veterinarian, Eugene, Oregon, USA

Ms. Priyanka Iyer, ZOO/WILD, Coimbatore, Tamil Nadu 641035, India

Dr. B. A. Daniel, $200 / \mathrm{WILD}$, Coimbatore, Tamil Nadu 641035, India

\section{Editorial Board}

Dr. Russel Mittermeier

Executive Vice Chair, Conservation International, Arlington, Virginia 22202, USA

\section{Prof. Mewa Singh Ph.D., FASc, FNA, FNASc, FNAPsy}

Ramanna Fellow and Life-Long Distinguished Professor, Biopsychology Laboratory, and Institute of Excellence, University of Mysore, Mysuru, Karnataka 570006, India; Honorary Professor, Jawaharlal Nehru Centre for Advanced Scientific Research, Bangalore; and Adjunct Professor, National Institute of Advanced Studies, Bangalore

\section{Stephen D. Nash}

Scientific Illustrator, Conservation International, Dept. of Anatomical Sciences, Health Sciences Center, T-8, Room 045, Stony Brook University, Stony Brook, NY 11794-8081, USA

\section{Dr. Fred Pluthero}

Toronto, Canada

\section{Dr. Priya Davidar}

Sigur Nature Trust, Chadapatti, Mavinhalla PO, Nilgiris, Tamil Nadu 643223, India

\section{Dr. Martin Fisher}

Senior Associate Professor, Battcock Centre for Experimental Astrophysics, Cavendish

Laboratory, JJ Thomson Avenue, Cambridge CB3 OHE, UK

\section{Dr. John Fellowe}

Honorary Assistant Professor, The Kadoorie Institute, 8/F, T.T. Tsui Building, The University of Hong Kong, Pokfulam Road, Hong Kong

\section{Prof. Dr. Mirco Solé}

Universidade Estadual de Santa Cruz, Departamento de Ciências Biológicas, Vice-coordenado do Programa de Pós-Graduação em Zoologia, Rodovia Ilhéus/Itabuna, Km 16 (45662-000)

Salobrinho, Ilhéus - Bahia - Brasil

\section{Dr. Rajeev Raghavan}

Professor of Taxonomy, Kerala University of Fisheries \& Ocean Studies, Kochi, Kerala, India

\section{English Editors}

Mrs. Mira Bhojwani, Pune, India

Dr. Fred Pluthero, Toronto, Canad

Mr. P. Ilangovan, Chennai, India

Web Maintenance

Mrs. Latha G. Ravikumar, ZOO/WILD, Coimbatore, India

\section{Typesetting}

Mr. Arul Jagadish, ZOO, Coimbatore, India

Mrs. Radhika, ZOO, Coimbatore, India

Mrs. Geetha, ZOO, Coimbatore India

\section{Fundraising/Communications}

Mrs. Payal B. Molur, Coimbatore, India

Subject Editors 2018-2020

Fungi

Dr. B. Shivaraju, Bengaluru, Karnataka, India

Dr. R.K. Verma, Tropical Forest Research Institute, Jabalpur, India

Dr. Vatsavaya S. Raju, Kakatiay University, Warangal, Andhra Pradesh, India

Dr. M. Krishnappa, Jnana Sahyadri, Kuvempu University, Shimoga, Karnataka, India

Dr. K.R. Sridhar, Mangalore University, Mangalagangotri, Mangalore, Karnataka, India

Dr. Gunjan Biswas, Vidyasagar University, Midnapore, West Bengal, India

Plants

Dr. G.P. Sinha, Botanical Survey of India, Allahabad, India

Dr. N.P. Balakrishnan, Ret. Joint Director, BSI, Coimbatore, India

Dr. Shonil Bhagwat, Open University and University of Oxford, UK

Prof. D.J. Bhat, Retd. Professor, Goa University, Goa, India

Dr. Ferdinando Boero, Università del Salento, Lecce, Italy

Dr. Dale R. Calder, Royal Ontaro Museum, Toronto, Ontario, Canada

Dr. Cleofas Cervancia, Univ. of Philippines Los Baños College Laguna, Philippines

Dr. F.B. Vincent Florens, University of Mauritius, Mauritius

Dr. Merlin Franco, Curtin University, Malaysia

Dr. V. Irudayaraj, St. Xavier's College, Palayamkottai, Tamil Nadu, India

Dr. B.S. Kholia, Botanical Survey of India, Gangtok, Sikkim, India

Dr. Pankaj Kumar, Kadoorie Farm and Botanic Garden Corporation, Hong Kong S.A.R., China

Dr. V. Sampath Kumar, Botanical Survey of India, Howrah, West Bengal, India

Dr. A.J. Solomon Raju, Andhra University, Visakhapatnam, India

Dr. Vijayasankar Raman, University of Mississippi, USA

Dr. B. Ravi Prasad Rao, Sri Krishnadevaraya University, Anantpur, India

Dr. K. Ravikumar, FRLHT, Bengaluru, Karnataka, India

Dr. Aparna Watve, Pune, Maharashtra, India

Dr. Qiang Liu, Xishuangbanna Tropical Botanical Garden, Yunnan, China

Dr. Noor Azhar Mohamed Shazili, Universiti Malaysia Terengganu, Kuala Terengganu, Malaysia Dr. M.K. Vasudeva Rao, Shiv Ranjani Housing Society, Pune, Maharashtra, India

Prof. A.J. Solomon Raju, Andhra University, Visakhapatnam, India

Dr. Mandar Datar, Agharkar Research Institute, Pune, Maharashtra, India

Dr. M.K. Janarthanam, Goa University, Goa, India

Dr. K. Karthigeyan, Botanical Survey of India, India

Dr. Errol Vela, University of Montpellier, Montpellier, France

Dr. P. Lakshminarasimhan, Botanical Survey of India, Howrah, India

Dr. Larry R. Noblick, Montgomery Botanical Center, Miami, USA

Dr. K. Haridasan, Pallavur, Palakkad District, Kerala, India

Dr. Analinda Manila-Fajard, University of the Philippines Los Banos, Laguna, Philippines

Dr. P.A. Sinu, Central University of Kerala, Kasaragod, Kerala, India

Dr. Afroz Alam, Banasthali Vidyapith (accredited A grade by NAAC), Rajasthan, India

Dr. K.P. Rajesh, Zamorin's Guruvayurappan College, GA College PO, Kozhikode, Kerala, India

Dr. David E. Boufford, Harvard University Herbaria, Cambridge, MA 02138-2020, USA

Dr. Ritesh Kumar Choudhary, Agharkar Research Institute, Pune, Maharashtra, India

Dr. Navendu Page, Wildlife Institute of India, Chandrabani, Dehradun, Uttarakhand, India

Invertebrates

Dr. R.K. Avasthi, Rohtak University, Haryana, India

Dr. D.B. Bastawade, Maharashtra, India

Dr. Partha Pratim Bhattacharjee, Tripura University, Suryamaninagar, India

Dr. Kailash Chandra, Zoological Survey of India, Jabalpur, Madhya Pradesh, India

Dr. Ansie Dippenaar-Schoeman, University of Pretoria, Queenswood, South Africa

Dr. Rory Dow, National Museum of natural History Naturalis, The Netherlands

Dr. Brian Fisher, California Academy of Sciences, USA

Dr. Richard Gallon, llandudno, North Wales, LL30 1UP

Dr. Hemant V. Ghate, Modern College, Pune, India

Dr. M. Monwar Hossain, Jahangirnagar University, Dhaka, Bangladesh

Mr. Jatishwor Singh Irungbam, Biology Centre CAS, Branišovská, Czech Republic

Dr. lan J. Kitching Natural History Museum, Cromwell Road, UK

Dr. George Mathew, Kerala Forest Research Institute, Peechi, India

Dr. John Noyes, Natural History Museum, London, UK

For Focus, Scope, Aims, and Policies, visit https://threatenedtaxa.org/index.php/JoTT/aims_scope
For Article Submission Guidelines, visit https://threatenedtaxa.org/index.php/JoTT/about/submissions
For Policies against Scientific Misconduct, visit https://threatenedtaxa.org/index.php/JoTT/policies_various 


\title{
Disentangling earthworm taxonomic stumbling blocks using molecular markers
}

\section{Azhar Rashid Lone ${ }^{1}$ (D), Samrendra Singh Thakur ${ }^{2}$ (D), Nalini Tiwari ${ }^{3}$ (D) Olusola B. Sokefun ${ }^{4}$ (D) \& Shweta Yadav ${ }^{5}$ iD}

\footnotetext{
1,3,5 Department of Zoology, Dr. Harisingh Gour Vishwavidyalaya (A Central University) Sagar, Madhya Pradesh 470003, India. 2 Department of Biotechnology Dr. Harisingh Gour Vishwavidyalaya (A Central University) Sagar, Madhya Pradesh 470003, India.

${ }^{4}$ Department of Zoology and Environmental Biology, Faculty of Science, Lagos State University, Ojo, 102101, Lagos, Nigeria. ${ }^{1}$ rashidazhar444@gmail.com, ${ }^{2}$ samrendra.thakur01@gmail.com, ${ }^{3}$ n.tiwari2987@gmail.com, ${ }^{4}$ osokefun@gmail.com,

${ }^{5}$ kmshweta@gmail.com (corresponding author)
}

\begin{abstract}
Taxonomic classification of earthworms based on anatomical features has created several challenges for systematics and population genetics. This study examines the application of molecular markers, in particular mitochondrial cytochrome oxidase (COI), to facilitate discrimination of closely related earthworm species. Molecular markers have also provided insights into population genetics by aiding assessment of genetic diversity, lineage sorting, and genealogical distributions of populations for several species. Phylogeography-a study that evaluates the geographical distribution of these genealogical lineages and the role of historical processes in shaping their distribution-has also provided insights into ecology and biodiversity. Such studies are also essential to understand the distribution patterns of invasive earthworm species that have been introduced in non-native ecosystems globally. The negative consequences of these invasions on native species include competition for food resources and altered ecosystems. We anticipate that molecular markers such as $\mathrm{COI}$ and DNA barcoding offer potential solutions to disentangling taxonomic impediments in earthworms and advancing their systematics and population genetics.
\end{abstract}

Keywords: Annelida, COI, cryptic species, genetic diversity, Invasive species, Oligochaeta, phylogeography, phylogeny.

Citation: Lone, A.R., S.S. Thakur, N. Tiwari, O.B. Sokefun \& S. Yadav (2021). Disentangling earthworm taxonomic stumbling blocks using molecular markers. Journal of Threatened Taxa 13(11): 19566-19579. https://doi.org/10.11609/jott.6888.13.11.19566-19579

Copyright: (C) Lone et al. 2021. Creative Commons Attribution 4.0 International License. JoTT allows unrestricted use, reproduction, and distribution of this article in any medium by providing adequate credit to the author(s) and the source of publication.

Funding: None.

Competing interests: The authors declare no competing interests.

Author details: AZHAR RASHID LONE is working on the phylogenetic systematics and population genetics of Indian earthworms in natural forests based on CO gene marker. SAMRENDRA SINGH THAKUR is working on the metagenomics, soil organic carbon management (SOC) through soil microbiome and bioremediation of contaminated soils in Madhya Pradesh, India. NALINI TIWARI is working on the phylogeny and phylogeography of Indian earthworms based on COI gene marker. OLUSOLA B. SOKEFUN is faculty at Lagos state University, Lagos, Nigeria and expert in phylogenetic analysis. PROF. SHWETA YADAV is a faculty at Dr. Harisingh Gour Vishwavidyalaya. She is an expert in molecular animal taxonomy of earthworms using various molecular markers. She focused her interest on the monitoring and conservation of fauna in natural forests of India.

Author contributions: ARL wrote the manuscript, SST and NT helped in data summarising, manuscript shaping, OSB helped in mining of phylogenetic data and SY enriched, curated and approved the final the submission of the final version of the manuscript.

Acknowledgements: Author SST is thankful to Environmental Planning and Coordination Organization (EPCO), Ministry of Environment, Govt. of Madhya Pradesh India for fellowship and SY to Department of Biotechnology, Ministry of Science and Technology, Govt. of India, New Delhi for the financial support to carry out the study. 


\section{INTRODUCTION}

The terrestrial Oligochaeta include annulated worms known as earthworms or megadriles, a group of invertebrate animals dispersed all over the world and having a paramount role in the development of burgeoning soil and its fertility (Lavelle et al. 1999; Edwards 2004). At present, the earthworms are investigated all over the world by approximately 300 specialists, most of them aiming at their ecology and role in terrestrial ecosystems. A few tens of earthworm scientists are considered to have expertise in Oligochaeta worm taxonomy and phylogeny. Terrestrial Oligochaeta has a relatively short and somewhat simple history. Started with the work of Savigny (1826), the study of earthworms gradually involved more specialists and consequently became more complicated as new characters and taxa were described. The contemporary terrestrial oligochaete taxonomy is considered as being rooted in the classical works of Rosa (1888-1944) and Michaelsen (1830-1930). Later Pop, Omodeo, Perrel, Zicsi, and Bouche contributed substantially to the knowledge of earthworm (especially Lumbricidae) taxonomy and phylogeny. The studies of earthworms got rapid worldwide development in the second half of the $20^{\text {th }}$ century with the development of soil science and soil zoology. Scientists all over the world were invigorated to study earthworms by the general acceptance of the idea of the soil, as indispensable for agriculture and must be carefully managed to avoid its irreversible deterioration. At that time, soil-inhabiting animals began to be looked as 'main soil builders' not only by a few zoologists, but by a large circle of specialists interested in improvement and conservancy of soil productivity. Only in a few decades, the main interest of specialists targeted more and more at the ecological aspects of soil inhabiting animals. More applicable fields were separated from the theoretical aspects by the processing of organic materials by earthworms. It also proved to merit protection from the negative effects of pesticides and even some fertilizers. A large section of scientists turned their interest to the study of earthworms. But at the same time, a classical field of earthworm taxonomy and phylogeny didn't magnify equally. The novelty and ecological approaches of the animal overlapped their basic studies. The majority of active scientists turned their interest to the ecology and application part of earthworms and the earthworm taxonomy was somewhat neglected or even considered to be outdated. Nevertheless, due to large-scale faunistic investigations, promoted by the biodiversity and ecosystem structure investigations, a lot of unknown taxa were found and described. The scarcity of skilled taxonomists led to the inflation of improperly described earthworm taxa and the appearance of parallel classification. Ecologists were firstly affected, but even specialists hardly succeeded to extricate the entangled stumbling block of earthworm taxonomy. It became obvious to develop a technology to resolve taxonomic impediments with the use of molecular tools while the traditional taxonomy and modern molecular taxonomy have contributed equally to the advancement of earthworm taxonomy.

Traditionally, earthworms are characterized based on classical approaches like morphological investigations of the external body and anatomybased dissections which take the advantage of limited taxonomic parameters like the structure of prostate, seminal vesicles, spermatheca, and calciferous glands (Lalthanzara et al. 2018). Moreover, due to simplicity of their structural organization, several diagnostic characteristics in earthworms are inconsistent and overlaps beyond taxon (Perez-Losada et al. 2009), their characterization requires experts which unfortunately are splurging. The shortage of discriminatory characters in earthworms was first divulged by Michaelsen (1900) and consequently defined these animals as 'sine systemate chaos'. Thus in all the domains of earthworm research, the existence of these taxonomic impediments is responsible for major prejudices. The use of a molecular approach may be a potential resolution to tackle the stumbling block of earthworm taxonomy. The use of a standard mitochondrial genetic marker often termed DNA barcoding has been, nowadays, considered as a reliable approach used in biodiversity studies as well as in species identification (Hebert et al. 2003, 2004). Chang et al. (2008) and Rougerie et al. (2009) have given voice to DNA barcoding as a potential solution to disentangle taxonomic impediments.

The study reviewed the prospective of molecular approaches including short sequences of the mitochondrial genome, in particular, the $\mathrm{COI}$ and its preponderance in resolving the stumbling block of earthworm taxonomy. The present study accentuates the contribution of this gene marker in deciphering taxonomic impediments primarily identification of species, phylogeny re-constructions, intraspecific variations; genetic structure, cryptic species, lineage sorting, and finally its role in the assessment of invasive species with phylogeographic tagging (Figure 1). 


\section{DNA Barcoding and Clitellate species identification}

Before DNA barcoding earthworm taxonomy relied on the specific morpho-anatomical features, however, most of these features often overlap among taxa and it became more inadequate when recently divergent species or species complexes were entertained (Chang \& James 2011). Although, the allozymes, RAPD, RFLP, and SSR techniques in the mid-19 $9^{\text {th }}$ century reflected the notion that certain earthworm species could be segregated. Nonetheless, due to their certain limitations including dominance and less reproducibility, the focus was given to the use of various gene markers to gain a better understanding of earthworm taxonomy (Kumari \& Thakur 2014). DNA barcode occupies $658 \mathrm{bp}$ of the mitochondrial genome for the recognition of animal species (Hebert et al. 2003). This method has diverse advantages; firstly, it is a rapid and cheaper technique in the case of massive samples for accurate identification. Secondly, it is reproducible and testable since it always keeps the record between any barcode and its voucher specimen. Above all, it could be applicable for tissues and applied to any life stages whether cocoons or a juvenile of any animal species as well as it is accessible everywhere around the globe (Rougerie et al. 2009). DNA barcoding has the potential for earthworm research in taxonomy and ecology (Decaëns et al. 2013). Moreover, in eco-toxicological studies, it is very essential to identify accurate model organisms for inferring toxicity of several compounds, as it is evident that many closely related species can react to the same toxicant differently. Otomo et al. (2009) highlighted the importance of DNA barcoding for the identification of earthworm species used in ecotoxicological tests and concluded that reliable identification is very crucial since it prevents various discrepancies when comparative studies are done involving different test species. Similarly, to evaluate the practicability and consistency of DNA barcoding, an international ring test was organized by Römbke et al. (2016) who assessed the genetic differentiation of two ecotoxicological earthworms, viz., Eisenia fetida and Eisenia andrei. These investigations have not only assessed the potential of DNA barcoding in taxon identification but specify that it could be the only way to measure an accurate level of biodiversity (Proudlove \& Wood 2003). The study of Richard et al. (2010) shows the potential of DNA barcoding can be applied to identify juvenile earthworm species in soils when reference DNA barcode library is available and thus highlighted that the bias in juvenile collection and identification could be highly reduced in earthworm biodiversity assessments. Moreover, many earthworm taxonomists emphasized that integrating morpho-anatomical features with barcoding data provide more contrasting conclusions. These integrative approaches were utilized to discriminate among species and taxa that are new to science (Shekhovtsov et al. 2014; Jeratthitikul et al. 2017; Lone et al. 2020). Furthermore, compared to morpho-anatomical features that require exhaustive work, species discrimination using DNA barcoding is relatively rapid and identification measure is progressed (Gregory 2005). These in turn have addressed certain issues, including rehabilitations, synonymies, and description of new taxa. Thus it sustains the decisions of nomenclature experts and thus primarily contributes to biodiversity assessments from local to global scales. Therefore, adopting DNA barcoding has enhanced the accuracy of earthworm studies and in particular, greatly benefited the community of soil biologists in the description of many novel species over the past few years (Blakemore 2013; Zhao et al. 2015; Aspe et al. 2016; Csuzdi et al. 2017; Seesamut et al. 2018; Lone et al. 2020); see Table 1 for more details. Furthermore, DNA barcoding has also shown its congruent results with other nuclear and mitochondrial genes (Pop et al. 2007; King et al. 2008) and many such papers are published in peer-reviewed journals. Furthermore, the nuclear and mitochondrial genes greatly differ in their divergence rates at different taxonomical levels. In many studies, it has been inferred that the mitochondrial gene particularly $\mathrm{COI}$ has the highest sequence divergences than other mitochondrial (12S, 16S) and nuclear genes (18S and 28S) (Chang \& James 2011). This indicates that at the species levels or intraspecific variations, species could be better studied when the fast-evolving genes like COI are considered. However, at higher taxonomical levels (within a genus or interfamilial) COI has a relatively weak signal than other slow evolving genes (18S, 28S) (Chang \& James 2011) and should be used at the species level or within genus if the genus is not too diverse. Thus, COI has been one of the most influential gene markers which have strongly revolutionized earthworm taxonomy by avoiding taxonomic confusions and providing additional evidence for discrimination of taxa over the past few years.

\section{Role in Phylogeny reconstructions}

Dobzhansky (1973) stated that in biology, nothing makes sense without the consideration of evolution. Since species undergo evolutionary changes, the relationship of these changes at all levels provides perception in the phylogenies of diverse species. The collaboration of morphological and molecular methods 
Table 1. List of publications based on molecular markers in earthworm diagnostics and taxonomy.

\begin{tabular}{|c|c|c|c|}
\hline Marker(s) & Main focus & Region(s) & Reference \\
\hline $\mathrm{COI}$ & New species (Pontodrilus longissimus) description & Thailand and Peninsular Malaysia & Seesamut et al. 2018 \\
\hline $\mathrm{COI}$ & $\begin{array}{l}\text { Description of new species Eisenia nordenskioldi } \\
\text { mongol and Eisenia nordenskioldi onon }\end{array}$ & Mongolia & Blakemore 2013 \\
\hline $\mathrm{COI} / \mathrm{ITS}$ & Aquatic oligochaetes identification & Switzerland & Vivien et al. 2015 \\
\hline $\mathrm{COI} /$ morphology & New taxa identification & Kamchatka & Shekhovtsov et al. 2014 \\
\hline $\begin{array}{l}\mathrm{COI} / 16 \mathrm{~S} / 18 \mathrm{~S} / 28 \mathrm{~S} / \\
\mathrm{H} 3 / \mathrm{H} 4 / \mathrm{tRNAs}\end{array}$ & $\begin{array}{l}\text { Description of new species Eiseniona gerardoi within } \\
\text { Lumbricidae }\end{array}$ & Extremadura, Spain & Cosín et al. 2014 \\
\hline $\begin{array}{l}16 \mathrm{~S} / 28 \mathrm{~S} / \mathrm{COI} / \mathrm{H} 3 / \\
\text { tRNAs }\end{array}$ & Description of new species Hormogaster joseantonioi & Teruel Aragon ranges, Aragon, Spain & Marchán et al. 2014 \\
\hline $\mathrm{COI}$ & DNA barcoding of Kanchuria species & Meghalaya, India & Lone et al. 2020 \\
\hline $\mathrm{COI}$ & DNA barcoding of Eutyphoeus species & Mizoram, India & Thakur et al. 2020 \\
\hline $\mathrm{COI}$ & DNA barcoding of earthworms species & Madhya Pradesh, India & Tiwari et al. 2020 \\
\hline $\mathrm{COI}$ & DNA barcoding & Thailand & Jeratthitikul et al. 2017 \\
\hline $\mathrm{COI} / 16 \mathrm{~S}$ & DNA barcoding and phylogeny in genus Glyphidrilus & Thailand & Jirapatrasilp et al. 2016 \\
\hline $\mathrm{COI}$ & DNA barcoding & Arunachal Pradesh, India & Lalthanzara et al. 2020 \\
\hline $\mathrm{COI}$ & DNA barcoding in Amynthas genus & Northeastern India & Vabeiryureilai et al. 2020 \\
\hline $\mathrm{COI}$ & DNA barcoding & Uruguay & Escudero et al. 2019 \\
\hline $\mathrm{COI}$ & Description of new taxa & Taiwanese montane & Chang et al. 2007 \\
\hline $\mathrm{COI}$ & DNA barcoding & China & Huang et al. 2007 \\
\hline $\mathrm{COI}$ & DNA barcoding & Taiwan & Chang et al. 2009 \\
\hline $\mathrm{COI}$ & DNA barcoding & $\begin{array}{l}\text { Canadian Centre for DNA Barcoding } \\
\text { (CCDB) }\end{array}$ & Rougerie et al. 2009 \\
\hline $\mathrm{COI}$ & DNA barcode for juvenile ID & Haute-Normandie, France & Richard et al. 2010 \\
\hline
\end{tabular}

has shaped significant progress in understanding the phylogeny of most major invertebrate groups (O'Grady \& DeSalle 2018). However, this is partially true for the earthworms which have not been resolved, although many attempts were made. About 100 years ago and throughout the greater part of the $20^{\text {th }}$ century oligochaetes, sensu stricto were classified into two main groups: Megadrila and Microdrili. The classification was based largely on two parameters; size and habitat preferences. The larger group that is confined to soils was termed Megadrili and the smaller group that is mostly restricted to water was called Microdrili (Benham 1890). Later Beddard (1895) compiled the basic structure laid out by Benham, however, redefined Microdrili by adding the family Naidomorpha' (presently called Naididae) a group that Benham considered as a subclass distinct from the rest of the oligochaetes. Following cladistic analysis and reclassification of Oligochaeta, Jamieson (1988) anticipated a new name for the Megadrili group, Metagynophora, based on the inferred loss of ovaries located anteriorly. He also proposed Crassicilitellata a less inclusive taxon for about 3,000 earthworms, containing multi-layered clitellum (composed of several epidermal cell layers). Whilst, other oligochaetes app.
120 Metagynophora species that mostly belonged to the family Alluroididae and Moniligastridae, outside Crassiclitellata, contained single-layered clitellum. The molecular phylogenetic analysis although started in the 1990s however, it was not until Siddall et al. (2001) for the first time focused on the phylogenetic study of leeches and their relatives that also included earthworms. Later, Jamieson et al. (2002) published their work on the phylogenetic study of earthworms and revealed monophyly of the Megascolecidae family based on $12 \mathrm{~S}, 18 \mathrm{~S}$, and $16 \mathrm{~S}$ data, besides it supported the clade Crassiclitellata (Jamieson 1988). Subsequently, many papers were published on the phylogeny of earthworms (Table 2). Moreover, to construct a phylogeny in earthworms, the selection of accurate markers would be essential. $\mathrm{COI}$ is preferred due to its simplicity of primer design and range of its phylogenetic signal (Hebert et al. 2003), rapid evolution to discriminate at the species level (Wishart \& Hughes 2003), and to provide informative features (Siddall et al. 2001; Pop et al. 2003; Heethoff et al. 2004; Chang \& Chen 2005; Pérez-Losada et al. 2005; Chang et al. 2007, 2008; Huang et al. 2007; King et al. 2008). Although many other genes are taken into consideration for the construction of phylogeny in 
Table 2. List of some peer reviewed publications in earthworm phylogeny and systematics.

\begin{tabular}{|c|c|c|c|}
\hline Marker(s) & Main focus & Region(s)/Platform & Reference \\
\hline $\mathrm{COI}$ & Phylogeny of Eisenia. nordenskioldi & Siberian and Korean & Hong \& Csuzdi 2016 \\
\hline $\mathrm{COI} / 16 \mathrm{~S} / 18 \mathrm{~S} / 28 \mathrm{~S} / \mathrm{H} 3 / \mathrm{H} 4 / \mathrm{tRNAs}$ & Hormogastridae phylogeny & $\begin{array}{l}46 \text { sites in the Iberian } \\
\text { Peninsula to Corsica and } \\
\text { Sardinia }\end{array}$ & Novo et al. 2011 \\
\hline $\mathrm{COI} / 16 \mathrm{~S} / 18 \mathrm{~S} / 28 \mathrm{~S} / \mathrm{H} 3 / \mathrm{H} 4 / \mathrm{tRNAs}$ & Phylogeny reconstruction of Hormogastridae & Mediterranean & Novo et al. 2015a \\
\hline COI/COII/12S/16S & Earthworm phylogeny genes & $\begin{array}{l}\text { Austria, Canada, USA, Russia, } \\
\text { Croatia, and Ireland }\end{array}$ & Klarica et al. 2012 \\
\hline $\begin{array}{l}\text { 18S/28S/12S/16S/ND1/COI } \\
\text { /COI/I/tRNAs }\end{array}$ & Phylogeny of Lumbricidae & Iran & Bozorgi et al. 2019 \\
\hline $\mathrm{COI} / \mathrm{COII} / 12 \mathrm{~S} / 16 \mathrm{~S} / 18 \mathrm{~S} / 28 \mathrm{~S} / \mathrm{ND} 1 / \mathrm{tRNAs}$ & Evolution of lumbricids & $\begin{array}{l}\text { Europe, USA, Brazil, Africa, } \\
\text { UK, China, Israel, Turkey, and } \\
\text { Vietnam }\end{array}$ & Domínguez et al. 2015 \\
\hline 28S/12S/16S/ND1/COII/tRNAs & Lumbricidae phylogeny & Northwestern Spain & Domínguez et al. 2017 \\
\hline COI/16S/ITS2 & $\begin{array}{l}\text { Phylogenetic analysis of the Dendrobaena } \\
\text { byblica }\end{array}$ & $\begin{array}{l}\text { Balkans, the Greek islands, } \\
\text { Anatolia, Levant and the } \\
\text { Carpathian Basin }\end{array}$ & Szederjesi et al. 2018 \\
\hline $\mathrm{COI}$ & Hormogastrid phylogeny & Iberian Peninsula & Novo et al. 2009 \\
\hline $\mathrm{COI}$ & $\begin{array}{l}\text { Phylogenetic relationships of Naidids } \\
\text { (Annelida) }\end{array}$ & GenBank & Bely \& Wray 2004 \\
\hline $\mathrm{COI} / 28 \mathrm{~S}$ & $\begin{array}{l}\text { Monophyly and phylogeny in Eisenia } \\
\text { fetida and Eisenia andrei }\end{array}$ & Ireland and Spain & Pérez-Losada et al. 2005 \\
\hline $12 \mathrm{~S} / 16 \mathrm{~S} / 28 \mathrm{~S} / \mathrm{COII} / \mathrm{ND} 1 / \mathrm{tRNAs}$ & $\begin{array}{l}\text { Phylogenetic relationships } \\
\text { of Aporrectodea caliginosa species complex }\end{array}$ & European earthworms & Pérez-Losada et al. 2009 \\
\hline $\mathrm{COI} / 12 \mathrm{~S} / 16 \mathrm{~S} / 28 \mathrm{~S} / \mathrm{H} 3 / \mathrm{ITS}$ & Phylogeny of Limnodrilus & $\begin{array}{l}\text { North America, Europe, } \\
\text { Japan, and China }\end{array}$ & Liu et al. 2017 \\
\hline $\mathrm{COI} / 16 \mathrm{~S} / \mathrm{H} 3 / \mathrm{ITS} 2$ & Cognettia diversity & Northern Europe & Martinsson \& Erséus 2014 \\
\hline $\mathrm{CO} 1 / \mathrm{CO} 2 / \mathrm{CO} 3 / \mathrm{Cytb} / \mathrm{ND} 5 / \mathrm{ND} 4 / 16 \mathrm{~S} / \mathrm{ND} 1$ & $\begin{array}{l}\text { Phylogenetic relationships of } \\
15 \text { Pheretima complex }\end{array}$ & China & Zhang et al. 2016 \\
\hline $\mathrm{COI} / \mathrm{COII} / 28 \mathrm{~S} / \mathrm{H} 3$ & Phylogeny of $A$. caliginosa complex & $\begin{array}{l}\text { Europe, UK, USA, Egypt, } \\
\text { Australia }\end{array}$ & Fernández et al. 2012 \\
\hline
\end{tabular}

earthworms (see Table 2), COI is generally engaged for its rapid divergence and fast-evolving features that aid in a better understanding of evolution and phylogeny reconstructions. Irrespective of being a vital role and promising idea that DNA barcoding has given to the molecular phylogenetics, the ongoing debates on earthworm systematics still face many key challenges that need to be addressed (Chang \& James 2011). Perhaps, these overwhelming challenges are not only confined to earthworms but also the whole Annelida. As McHugh (2001) stated that the poor resolution at higher levels in Clitellata is due to radiation or rapid divergence of annelid phylogeny and Martin et al. (2000) stated the same reasons for Clitellata phylogeny which was also supported by the investigation of Maekawa et al. (2001) and Su et al. (2001). This demands further research and large datasets to answer the key questions in Clitellata phylogeny. Although the molecular phylogenetic investigations were studied in the family Eudrilidae, Ocnerodrilidae, Lumbricidae, Megascolecidae, and Glossocolecidae, however, except for the support of the monophyly in Megascolecidae, the support for all the families is weak due to insufficient sampling and taxon bias. Moreover, in the family Lumbricidae, the focus is given to within genus (Aporrectodea) Allolobophora, Dendrobaena, and Octodriloides/ Octodrillus/Octolasion) which led to restating the polyphyletic nature of Allolobophora and synonymizing Octodrilus with Octodriloides, nonetheless, there was no significant progress in phylogenetic revision (Pop \& Wink 2004; Pop et al. 2003, 2007, 2008; Cech et al. 2005). Thus we can anticipate that the phylogeny of the oligochaetes Clitellata still encompasses various challenges in the present scenario, and requires further development for in-depth phylogenetic information. Moreover, DNA barcoding has no doubt interpreted many findings either alone or with the combination of other genes however, more data is required to tackle many challenges in phylogenetic studies in Clitellata and lastly the more densely the taxa are sampled, the more defined the phylogenetic estimations will be measured (Erséus 2005). 


\section{Unveiling cryptic species/species complex/intraspecific divergence in Clitellata}

In the biological process, cryptic speciation results in a species group, containing individuals that are morphologically identical to each other however belong to different species (Pérez-Losada et al. 2005). With morpho-anatomical features, most of the cryptic species/species complexes remain unnoticed and it was not until with the availability of DNA sequences there was an increase in the number of cryptic species (Torres-Leguizamon et al. 2014; Marchán et al. 2017). In earthworm taxonomy, the identification of taxa at higher taxonomical levels particularly at genus or interfamilial levels can be studied effectively as there are many taxonomical characteristics that could be applied to assign taxa at family and genus levels (Pérez-Losada et al. 2005). However, when closely related species and species complexes are considered, few morphoanatomical features are available and it makes taxonomy more complicated when these morpho-anatomical features overlap among them (Lalthanzara et al. 2018). Thus at the species level or when dealing with cryptic species, the taxonomic methods are complicated, exhaustive, labor-consuming, and demands expertise in the field (Lalthanzara et al. 2018; Thakur et al. 2020). Furthermore, due to simple body structures in earthworms, their identification is limited to mature specimens as the key taxonomical features can only be applied to them, leaving juveniles or closely related species unidentified. With DNA barcoding several cryptic species/ species complexes are identified in earthworms, most of which are widespread in several families; Lumbricidae (Heethoff et al. 2004; King et al. 2008; Fernández et al. 2011; Shekhovtsov et al. 2013, 2016a), Mediterranean Hormogastridae (Novo et al. 2010, 2011), Megascolecidae (Chang et al. 2008; Buckley et al. 2011), Glossoscolecidae (de Faria et al. 2013) respectively (see Table 3 for more published papers). Moreover, the development of DNA barcoding cryptic species in earthworms has gained pace as more and more data is being added which not only tells us the extensive occurrence of cryptic diversity in earthworms but the action of various ecological processes that has led to these divergences within them. Furthermore, many investigations revealed that several earthworm taxa may contain two to five cryptic lineages with app. 10-20\% of nucleotide substitutions among them (Nova et al. 2009; Buckley et al. 2011; Porco et al. 2013; Fernández et al. 2016). In soil-dwelling invertebrates particularly earthworms the occurrence of these cryptic lineages is common due to allopatric isolation which restricts gene flow between regions of suitable habitat (Hogg et al. 2006) as well as minimizes the change in morphological characters taking place during speciation (Bickford et al. 2007).

In addition to this, the different individuals of a given species are not genetically identical. Their DNA sequences differ to some extent, and these differences form the genetic diversity, known as the intraspecific diversity of a species (Stange et al. 2020). These genomic variations are the basic foundation of biodiversity. It refers to a process by which the characteristics of living organisms change over many generations and addresses how different species are related through the complicated family trees. Understanding diversity at the genomic level including an arrangement in taxonomic standards is, therefore, the most important parameter of biodiversity. The importance of genetic variation in biodiversity evaluation has been well recognized (Des Roches et al. 2018). Nonetheless, such studies cannot be accomplished entirely based on simple morphological examinations of different taxa and therefore demand molecular investigations to provide more tangible understandings of earthworm diversity indices. Moreover, molecular studies, for example, systematic studies involve molecular data to reveal variation among the population as well as among species. However, molecular systematics rely largely on empirical results: therefore, increasing knowledge about rates of nucleotide change is needed to improve assumptions generally used for phylogenetic inferences and deciphering the evolutionary process within or between species. While phylogenetic relationships can be deciphered through analysis of DNA sequences among species, comparisons of DNA barcodes within species furnish information about the population structure of species and their evolutionary history.

In earthworms despite their fundamental importance in soil ecosystems, their population structure as a function of intraspecific diversity or genetic diversity is poorly understood and the amount of these studies are scanty, due to either less attention that was given to earthworms or other vertebrates were studied utmost. Presently limited investigations such as the role of glacial periods and contemporary processes like habitat fragmentation on the genetic diversity (see Table 3 ) of earthworms are studied based on the partial sequencing of COI gene and other markers (COII, 12S, 16S, 18S, 28S, H3, H4, tRNAs) and this has opened up new challenges in the field of population genetics. Earthworms have a complicated pattern of gene flow with a weak relationship between genetic and geographic distances. 
Table 3. Depicts the peer reviewed published literature of cryptic speciation/ species complex/ intraspecific divergence in earthworms.

\begin{tabular}{|c|c|c|c|}
\hline Marker(s) & Main focus & Region(s) & Reference \\
\hline $\mathrm{COI}$ morphological characteristics & Ecological process and diversification & $\begin{array}{l}\text { Tropical rainforests of } \\
\text { French Guiana. }\end{array}$ & Decaëns et al. 2016 \\
\hline $\mathrm{COI}$ & Genetic diversity and cryptic species of $E$. andrei & South Africa & Voua et al. 2013 \\
\hline $\mathrm{COI} / 16 \mathrm{~S}$ & Genetic differentiation and phylogeny of Drawida ghilarovi & Russian Far East & Atopkin \& Ganin 2015 \\
\hline COI/AFLP & $\begin{array}{l}\text { Cryptic lineages in Allolobophora chlorotica, A. longa, A. } \\
\text { rosea, and Lumbricus rubellus }\end{array}$ & British earthworms & King et al. 2008 \\
\hline $\mathrm{COI} / \mathrm{ITS} 2$ & Genetic variations of Eisenia nordenskioldi pallida & Northern Asia & Shekhovtsov et al. 2016a \\
\hline $\mathrm{COI}$ & Genetic diversity within $A$. caliginosa & $\begin{array}{l}\text { Eastern Europe to the } \\
\text { Russian Far East }\end{array}$ & Shekhovtsov et al. $2016 \mathrm{c}$ \\
\hline $\mathrm{COI} / \mathrm{COII} / 28 \mathrm{~S} / \mathrm{H} 3$ & Clonal diversity in $A$. trapezoides & Europe, Algeria, Egypt & Fernández et al. 2011 \\
\hline $\mathrm{COI} / 16 \mathrm{~S} / 28 \mathrm{~S} / \mathrm{tRNAs}$ & Genetic differentiation in Hormogastrid earthworms & Iberian Peninsula & Nova et al. 2010 \\
\hline COI/ATP6 & Lineages of the earthworm Lumbricus rubellus & Poland & Giska et al. 2015 \\
\hline $\mathrm{COI} / \mathrm{H} 3$ & Cryptic lineages in L. terrestris, L. herculeus and L. rubellus & Northern Europe, USA & Martinsson \& Erséus 2017 \\
\hline COI/ITS2 & $\begin{array}{l}\text { Genetic variations in Eisenia nordenskioldi subsp. } \\
\text { nordenskioldi (Eisen, 1879) populations and other } \\
\text { lumbricids }\end{array}$ & $\begin{array}{l}\text { Geographically remote } \\
\text { areas of Siberia }\end{array}$ & Shekhovtsov et al. 2013 \\
\hline $\mathrm{COI}$ & Lineage diversity in L. rubellus & Britain & Donnelly et al. 2014 \\
\hline COI/16S/28S/H3/tRNAs & Cryptic speciation in H. elisae populations & $\begin{array}{l}\text { Center of the Iberian } \\
\text { Peninsula }\end{array}$ & Marchán et al. 2017 \\
\hline $\mathrm{COI} / 7$ microsatellite loci & $\begin{array}{l}\text { Cryptic diversity and geography of Aporrectodea icterica } \\
\text { populations }\end{array}$ & France & $\begin{array}{l}\text { Torres-Leguizamon et al. } \\
2014\end{array}$ \\
\hline $\mathrm{COI}$ & Cryptic lineages in Lumbricus terrestris & Europe, northern America & James et al. 2010 \\
\hline $\mathrm{COI}$ & Genetic diversity of $E$. n. nordenskioldi & $\begin{array}{l}\text { Southern Urals and } \\
\text { eastern Europe }\end{array}$ & Shekhovtsov et al. $2016 \mathrm{~b}$ \\
\hline $\mathrm{COI} / 16 \mathrm{~S} / 28 \mathrm{~S} / \mathrm{H} 3 / \mathrm{H} 4 / \mathrm{tRNAs}$ & $\begin{array}{l}\text { Genetic variability and cladogenesis in Aporrectodea } \\
\text { rosea and A. trapezoids }\end{array}$ & $\begin{array}{l}\text { Spain, France, Italy and } \\
\text { Algeria }\end{array}$ & Fernández et al. 2016 \\
\hline $\mathrm{COI} / 5.8 \mathrm{~S} / \mathrm{ITS} 1 / \mathrm{ITS} 2$ & Genetic diversity in Rhinodrilus alatus and R. motucu & $\begin{array}{l}\text { Southeastern Brazil } \\
\text { savannah }\end{array}$ & $\begin{array}{l}\text { de Faria Siqueira et al. } \\
2013\end{array}$ \\
\hline
\end{tabular}

Kautenburger (2006) studied the genetic structure of $L$ umbricus terrestris $L$ populations at different locations in Germany and revealed an absence of isolation by distance pattern. Similar observations were inferred by Cameron et al. (2008) while investigating Dendrobaena octaedra populations in Alberta, Canada. They pointed out that the anthropogenic activities mainly 'bait abandonment' and limited active dispersal abilities lead to the significant population differentiation of $D$. octaedra. These results are related to the ideas of Sakai et al. (2001) who underlined that earthworms have limited active dispersal and it is often animal-mediated transport or limited active dispersal abilities causing genetic differentiation patterns. The genetic variations in the infields and the outfields of Lumbricus rubellus, caused by the selection of effective land-use practices (example infield eutrophication) was studied by Enckell et al. (1986) while Terhivuo \& Saura (1993) stated that the high clonal diversity of Aporrectoda rosea is attributed to dispersal activities through agricultural practices in southern Finland. Terhivuo \& Saura (1997) emphasize that human activities are the main cause of passive dispersal in Octolasion cyaneum in northern Europe. Contrary to these results the reports of Novo et al. (2009) reflected that Hormogaster elisae contained cryptic species and the genetic differentiation was primarily based on the isolation by distance mechanism. The work of TorresLeguizamon et al. (2014) on earthworm populations of Aporrectodea icterica reflected low genetic polymorphism and that the human-mediated favors dispersal among geographically distinct populations. Therefore these studies indicate that the population genetic structure of earthworms is strongly influenced by human activities. Giska et al. (2015) while studying the lineages of Lumbricus rubellus of the UK revealed that the mitochondrial lineages are deeply divergent, however not reproductive isolated and therefore may constitute a single polymorphic species rather than a complex of cryptic species. More recently, Ganin \& Atopkin (2018) studied the molecular differentiation of two ecological and three color morphs of Drawida ghilarovi. They concluded strong genetic differentiation in two ecological forms (anecic and epigeic) with the presence of several genetic lineages in anecic forms. The genetic diversity of Amynthas triastriatus populations revealed two genetic lineages that were split at 2.58 
$\mathrm{Ma}$ at the time of Quaternary glaciation in southern China as the authors (Dong et al. 2020) suggested that parthenogenesis could be an internal factor that influenced the genetic differentiation and dispersal of $A$. triastriatus. Taking together these studies, it can be anticipated that the Clitellata and in particular earthworms are heterogeneous groups and are prone to genetic differentiation. The genetic heterogeneity is due to cryptic speciation (King et al. 2008) or the amphigonic and polyploidy strains within populations (Casellato 1987). Yet, whatever the possible reasons that gave rise to genetic heterogeneity, the evolutionary and ecological consequences of its existence are ranging extensively. Furthermore, more data is required in terms of $\mathrm{COI}$ barcodes along with the sequencing of other mitochondrial (COII, 12S, 16S) and nuclear genes (18S, 28S) to understand how earthworms move in soils, how ecological and anthropogenic activates affect the gene flow and selection in earthworms, and how environmental stressors are manipulating the genetic differentiation in various populations of earthworm species. These studies could be essential to understand environmental changes through these 'unsung heroes' of the soil.

\section{Phylogeography and earthworm invasions}

Phylogeography is an emerging field that evaluates the geographical distribution of genealogical lineages. It is based on the analysis of DNA variations from individuals across a species range to reconstruct gene genealogies. To infer historical biogeographic events in species, phylogeography became a potent tool to understand the role of historical processes in shaping the distribution of biological species (Avise 2000). It has its role in invasion biology by improving the knowledge of invasive species. Since, the speed of invasion has dramatically increased over the past several decades due to enhanced globalization, as a result of being transported to other continents via trade either deliberately or unintentionally. This has caused the transmission of several species to other regions across water bodies where they usually are absent and now have become recognized beyond their natural ranges (Hulme 2009). Moreover, once these non-native species invade native terrestrial ecosystems, they often compete for the resources thus out-competing native species. This has attracted many ecologists and conservationists to pinpoint their concerns including alterations in native ecosystems as well threats to the native species, biodiversity, and economy (Tsutsui et al. 2000; Pejchar \& Mooney 2009; Vilà et al. 2011; Qiu 2015). To overcome the invasion of these invasive species we not only need to understand their relationship with native ecosystems in terms of dynamics and establishments but also the knowledge of the history of their invasion and ecology. Nonetheless, in some instances, we even do not know the systematics of these invading species taxa (Yassin et al. 2008; Folino-Rorem et al. 2009; Bastos et al. 2011) and this makes it more problematic to predict and manage the invasion issues. Thus, the study of phylogeography is essential in the sense that it tells us the history of invasive species and the exploration of their cryptic diversity. Therefore, apart from predicting its diversity phylogeography helps in the management of the spreading of invasive species (Schult et al. 2016). Since phylogeography is based on the DNA sequences of the genome or molecular markers, the variations of patterns in DNA sequences of these molecular markers leads to the conclusions of how biogeographic events took place in all geographic scales ranging from continental to local (Avise et al. 1987; Avise 2000). Moreover, a phylogenetic tree reveals clear results of how demographic and phylogeographic forces together constitute the lineage distribution of species. Therefore, to construct a phylogeny and to depict phylogeography of taxa, the selection of accurate markers would be essential. Amongst these various molecular markers the mitochondrial genes (COI, COII, 12S, 16S) especially $\mathrm{COI}$ is ideal while inferring phylogeography and invasion of various terrestrial species (Chang et al. 2008; Porco et al. 2013; Shekhovtsov et al. 2018a,b). Subsequently, most of these invasions are taking place in terrestrial ecosystems therefore, it is vital to understand the ecology, population dynamics of these invading species before setting management protocols to overcome their ecological effects. Earthworms being most dominant in terrestrial soils have profound ecological consequences especially in soils where they actively participate in nutrient cycling and other soil dynamic functions (Edwards 2004). Since earthworms are an archaic invertebrate animal group, their phylogeography is quite restricted due to their little mobilities in soils and incompetency to cross rivers, seas, and mountains. However, earthworms have been widespread recently due to two main reasons: via agriculture and commerce carried by humans across the globe and secondly, the introduction of earthworms in soils for their effective functions. For example, in the coniferous forests of Finland (Huhta 1979) Aporrectodea caliginosa was introduced to enhance its promising results. Similarly, earthworm invasions with their middens and burrowing activities have no doubt enhance soil heterogeneity 
Table 4. List of publications of phylogeography and invasion of earthworm using COI and other molecular markers.

\begin{tabular}{|l|l|l|l|}
\hline Marker(s) & Main focus & Region(s) \\
\hline $\mathrm{COI}$ & Genetic structure, and invasions earthworms and Collembola & Europe and North America & Porco et al. 2013 \\
\hline $\mathrm{COI}$ & Introduction earthworm Dendrobaena octaedra & Northern Alberta & Cameron et al. 2008 \\
\hline $\mathrm{COI} / 16 \mathrm{~S}$. & the invasion history of Amynthas agrestis & Northern United States & Nancy et al. 2016 \\
\hline $16 \mathrm{~S} / \mathrm{COI} / \mathrm{ND} 1$ & Systematics and phylogeography of Metaphire formosae species & Taiwan & Chang et al. 2008 \\
\hline $\mathrm{COI} / 16 \mathrm{~S}$ & Historical phylogeography of Metaphaire sieboldi & Japan & Russia \\
\hline $\mathrm{COI}$ & Phylogeography of E.n. nordenskioldi populations et al. 2009 & Shekhovtsov et al. 2018a \\
\hline $\mathrm{COI}$ & $\begin{array}{l}\text { Dendrobaena octaedra, Lumbricus rubellus, and Eisenia nordenskioldi } \\
\text { nordenskioldi }\end{array}$ & Eurasia & Shekhovtsov et al. 2018b \\
\hline
\end{tabular}

and abundance of other soil invertebrates by creating microhabitats with larger pore sizes and high microbial biomass that attract micro and mesofauna, respectively. However, such functions are often transient, small, and restricted to soil habitats, and rather the invasion has more negative effects. For instance, the invasion of the Amynthas species that belong to the Asian Megascolecidae family has drawn major concerns in the United States and several studies have investigated their consequences in non-native habitats (Hendrix \& Bohlen 2002; Schult et al. 2016). The study of Cameron et al. (2008) revealed single and multiple invasions of earthworm Dendrobaena octaedra in the boreal forest of Alberta. Similarly, Novo et al. (2015b) studied the invasion of Amynthas species namely A. corticis and $A$. gracilis in Miguel islands in the Azores. Table 4 provides details of some peer-reviewed papers on phylogeography and invasion of earthworm species. Thus, in the longer term, the invasion of non-native earthworms can have strong adverse impacts on native faunal groups. Other studies either field or laboratory-based investigations also provide strong evidence of physical disturbance to the soil, food competition, vegetation loss, alteration of organic horizons, and decline of significant micro and mesofauna in soils due to invasions (Bohlen et al. 2004a,b; Frelich et al. 2006). Thus, the concern of nonnative earthworm species should be addressed primarily and more focus should be given to their population dynamics, cryptic speciation, and phylogeography to understand the network of their invasion and to overcome their consequences by providing enough unbiased sampling and DNA based datasets.

\section{CONCLUSION}

Regardless of the fact that earthworm fauna of India is well reported as compared to other Asian Countries mainly on the basis of classical taxonomy but to solve a large number of taxonomic disagreement, an integrated approach of taxonomy may be promising in this direction. Molecular systematics of Indian earthworms is at nascent because of limited molecular database. A total of 801 DNA sequences of Indian earthworm are available on the BOLD database, while limited numbers are published yet. It is difficult to count them for correct identification unless they published. In spite of seemingly promising idea of molecular phylogenetic of earthworms a lack of comparative phylogenetic and phylogeographic inference have been observed. To overcome the current muddle of taxonomic puzzle of earthworms there is a need to move on towards integrated taxonomy.

\section{REFERENCES}

Aspe, N.M., H. Kajihara \& S.W. James (2016). A molecular phylogenetic study of pheretimoid species (Megascolecidae) in Mindanao and associated islands, Philippines. European Journal of Soil Biology 73: 119-125. https://doi.org/10.1016/j.ejsobi.2016.02.006

Atopkin, D.M. \& G.N. Ganin (2015). Genetic differentiation of black and grey colored forms of the earthworm Drawida ghilarovi Gates, 1969 (Moniligastridae, Oligochaeta) on Russian Far East. European Journal of Soil Biology 67: 12-16. https://doi.org/10.1016/j. ejsobi.2014.12.003

Avise, J.C. (2000). Phylogeography: The History and Formation of Species. Harvard University Press, Cambridge, 447 pp.

Avise, J.C., J. Arnold, R.M. Ball, E. Bermingham, T. Lamb, J.E. Neigel, C.A. Reeb \& N.C. Saunders (1987). Intraspecific phylogeography: the mitochondrial DNA bridge between population genetics and systematics. Annual Review of Ecology, Evolution and Systematics 18(1): 489-522. https://doi.org/10.1146/annurev. es.18.110187.002421

Bastos, A.D., D. Nair, P.J. Taylor, H. Brettschneider, F. Kirsten, E. Mostert, E. Von Maltitz, J.M. Lamb, P. Van Hooft, S.R. Belmain \& G. Contrafatto (2011). Genetic monitoring detects an overlooked cryptic species and reveals the diversity and distribution of three 


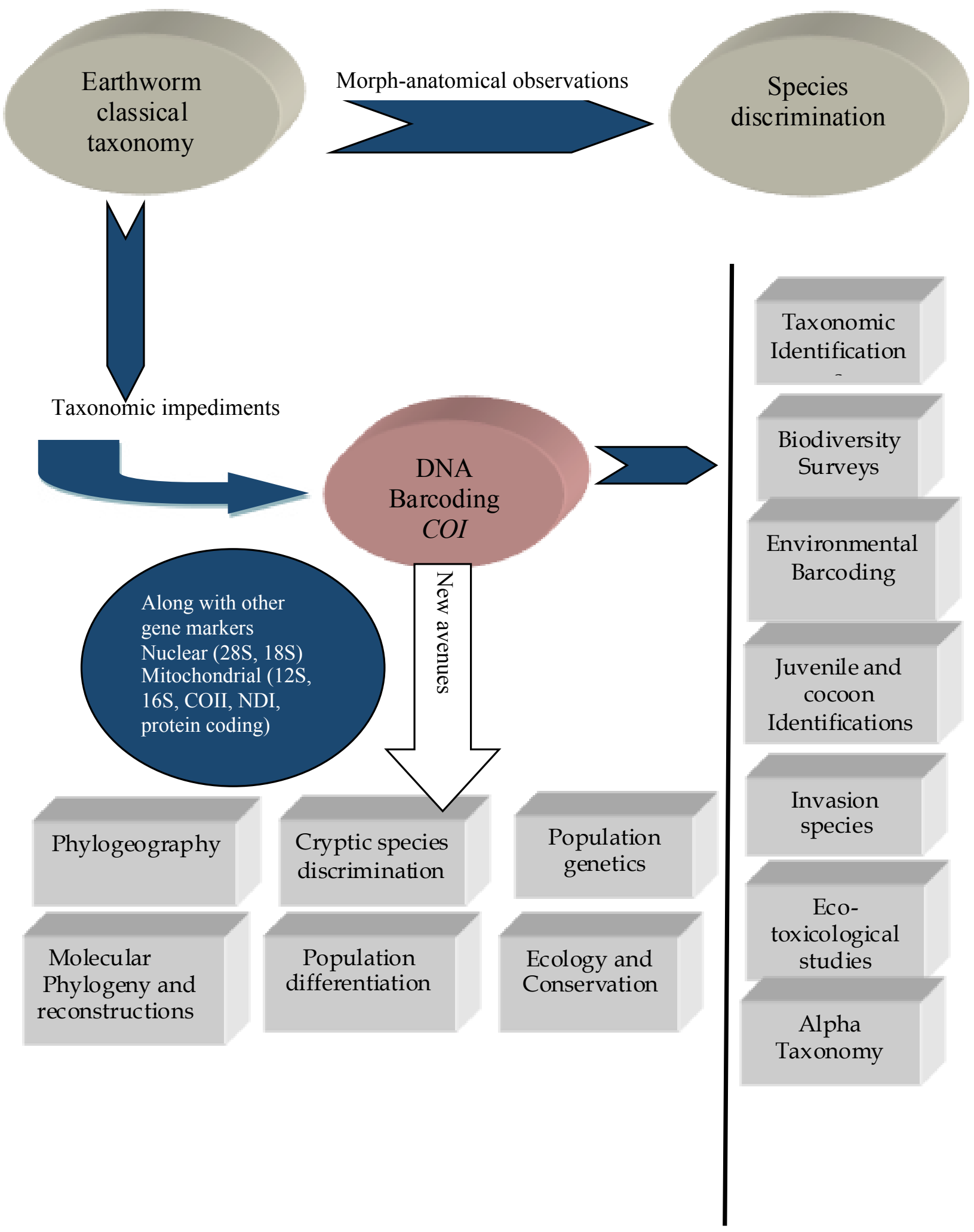

Figure 1. Lay out of charcterization and phylogenetic analysis of taxon using molecular markers and their appilications in systematics, genetic diversity, and ecological studies of earthworms. 
invasive Rattus congeners in South Africa. BMC Genetics 12(1): 1-18. https://doi.org/10.1186/1471-2156-12-26

Beddard, F.E. (1895). A monograph of the order of Oligochaeta. Clarendon press, Oxford, 753 pp. https://doi.org/10.5962/bhl. title. 56335

Bely, A.E. \& G.A. Wray (2004). Molecular phylogeny of naidid worms (Annelida, Clitellata) based on cytochrome oxidase I. Molecular Phylogenetic Evolution 30(1): 50-63. https://doi.org/10.1016/ S1055-7903(03)00180-5

Benham, W.B. (1890). An attempt to classify earthworms. Quarterly Journal of Microscopical Society (NS) 33: 201, 315

Bickford, D., D.J. Lohman, N.S. Sodhi, P.K. Ng, R. Meier, K. Winker, K.K. Ingram \& I. Das (2007). Cryptic species as a window on diversity and conservation. Trends in Ecology and Evolution 22(3): 148-155 https://doi.org/10.1016/j.tree.2006.11.004

Blakemore, R.J. (2013). Earthworms newly from Mongolia (Oligochaeta, Lumbricidae, Eisenia). ZooKeys 285: 1-21. https://doi. org/10.3897/zookeys.285.4502

Bohlen, P.J., P.M. Groffman, T.J. Fahey, M.C. Fisk, E. Suárez, D.M. Pelletier \& R.T. Fahey (2004a). Ecosystem consequences of exotic earthworm invasion of north temperate forests. Ecosystems $7(1)$ : 1-12. https://doi.org/10.1007/s10021-003-0126-z

Bohlen, P.J., D.M Pelletier, P.M. Groffman, T.J. Fahey \& M.C. Fisk (2004b). Influences of earthworm invasion on redistribution and retention of soil carbon and nitrogen in northern temperate forests. Ecosystems 7(1): 13-27. https://doi.org/10.1007/s10021-0030127-y

Bozorgi, F., M. Seiedy, M. Malek, M. Aira, M. Pérez-Losada \& J. Domínguez (2019). Multigene phylogeny reveals a new Iranian earthworm genus (Lumbricidae: Philomontanus) with three new species. PLoS One. 14(1): e0208904. https://doi.org/10.1371/ journal.pone.0208904

Buckley, T.R., S. James, J. Allwood, S. Bartlam, R. Howitt \& D. Prada (2011). Phylogenetic analysis of New Zealand earthworms (Oligochaeta. Megascolecidae) reveals ancient clades and cryptic taxonomic diversity. Molecular Phylogenetics Evolution 58(1): 8596. https://doi.org/10.1016/j.ympev.2010.09.024

Cameron, E.K., E.M. Bayne \& D.W. Coltman (2008). Genetic structure of invasive earthworms Dendrobaena octaedra in the boreal forest of Alberta: insights into introduction mechanisms. Molecular Ecology 17(5): 1189-1197. https://doi.org/10.1111/j.1365 294X.2007.03603.x

Casellato, S. (1987). On polyploidy in Oligochaetes with particular reference to Lumbricids, pp. 75-87. In: Pagliai A.M.B. \& P. Omodeo (eds.). On Earthworms. Mucchi, Modena.

Cech, G., C. Csuzdi \& K. Marialigeti (2005). Remarks on the molecular phylogeny of the genus Dendrobaena (sensu Pop 1941) based on the investigation of $18 \mathrm{~S}$ rDNA sequences, pp. 85-98. In: Pop, A.A. \& V.V. Pop (eds.). On Advances in Earthworm Taxonomy II (Annelida: Oligochaeta). Cluj University Press, Romania.

Chang, C.H. \& J.H. Chen (2005). Taxonomic status and intraspecific phylogeography of two sibling species of Metaphire (Oligochaeta: Megascolecidae) in Taiwan. Pedobiologia 49(6): 591-600. https:// doi.org/10.1016/j.pedobi.2005.07.002

Chang, C.H. \& S. James (2011). A critique of earthworm molecular phylogenetics. Pedobiologia 54: S3-S9. https://doi.org/10.1016/j. pedobi.2011.07.015

Chang, C.H., S.M. Lin \& J.H. Chen (2008). Molecular systematics and phylogeography of the gigantic earthworms of the Metaphire formosae species group (Clitellata:Megascolecidae). Molecular Phylogenetics Evolution 49(3): 958-968. https://doi.org/10.1016/j. ympev.2008.08.025

Chang, C.H., Y.H. Lin, I.H. Chen, S.C. Chuang \& J.H. Chen (2007) Taxonomic re-evaluation of the Taiwanese montane earthworm Amynthas wulinensis Tsai, Shen \& Tsai, 2001 (Oligochaeta: Megascolecidae): polytypic species or species complex? Organisms Diversity \& Evolution 7(3): 231-240. https://doi.org/10.1016/j ode.2006.06.001

Chang, C.H., R. Rougerie \& J.H. Chen (2009). Identifying earthworms through DNA barcodes: Pitfalls and promise. Pedobiologia 52(3): 171-180. https://doi.org/10.1016/j.pedobi.2008.08.002

Cosín, D.J.D., M. Novo, R. Fernández, D.F. Marchán \& M. Gutiérrez (2014). A new earthworm species within a controversial genus: Eiseniona gerardoi sp. n. (Annelida: Lumbricidae) description based on morphological and molecular data. ZooKeys 399: 71-87. https:// doi.org/10.3897/zookeys.399.7273

Csuzdi, C., C.H. Chang, T. Pavlícek, T. Szederjesi, D. Esopi \& K. Szlávecz (2017). Molecular phylogeny and systematics of native North American lumbricid earthworms (Clitellata: Megadrili). PLoS One 12(8): e0181504. https://doi.org/10.1371/journal.pone.0181504

de Faria Siqueira, F., S.H. de Cicco Sandes, M.A. Drumond, S.H. Campos, R.P. Martins, C.G. da Fonseca \& M.R.S. Carvalho (2013). Genetic diversity and population genetic structure in giant earthworm Rhinodrilus alatus (Annelida: Clitellata: Glossoscolecidae). Pedobiologia 56(1): 15-21. https://doi. org/10.1016/j.pedobi.2012.08.006

Decaëns, T., D. Porco, S.W. James, G.G. Brown, V. Chassany, F. Dubs, L. Dupont, E. Lapied, R. Rougerie, J.P. Rossi \& V. Roy (2016). DNA barcoding reveals diversity patterns of earthworm communities in remote tropical forests of French Guiana. Soil Biology \& Biochemistry 92: 171-183. https://doi.org/10.1016/j.soilbio.2015.10.009

Decaëns, T., D. Porco, R. Rougerie, G.G. Brown \& S.W. James (2013). Potential of DNA barcoding for earthworm research in taxonomy and ecology. Applied Soil Ecology 65: 35-42. https://doi.org/10.1016/j. apsoil.2013.01.001

Des Roches, S., D.M. Post, N.E. Turley, J.K. Bailey, A.P. Hendry, M.T. Kinnison, J.A. Schweitzer \& E.P. Palkovacs (2018). The ecological importance of intraspecific variation. Nature Ecology \& Evolution 2(1): 57-64. https://doi.org/10.1038/s41559-017-0402-5

Dobzhansky, T. (1973). Nothing in Biology makes Sense Except in the light of Evolution. The American Biology Teacher 35: 125-129. https://doi.org/10.2307/4444260

Domínguez, J., M. Aira, J.W. Breinholt, M. Stojanovic, S.W. James \& M. Pérez-Losada (2015). Underground evolution: new roots for the old tree of lumbricid earthworms. Molecular Phylogenetics and Evolution 83: 7-19. https://doi.org/10.1016/j.ympev.2014.10.024

Domínguez, J., M. Aira, P.G. Porto, D.J. Díaz Cosín \& M. Pérez-Losada (2017). Multigene phylogeny reveals two new isolated and relic earthworm genera (Oligochaeta: Lumbricidae). Zoological Journal of the Linnean Society 182(2): 258-274. https://doi.org/10.1093/ zoolinnean/zlx031

Dong, Y., J. Jiang, Z. Yuan, Q. Zhao \& J. Qiu (2020). Population genetic structure reveals two lineages of Amynthas triastriatus (Oligochaeta: Megascolecidae) in China, with notes on a new subspecies of Amynthas triastriatus. International Journal of Environmental Research and Public Health 17(5): 1538. https://doi.org/10.3390/ ijerph17051538

Donnelly, R.K., G.L. Harper, A.J. Morgan, G.A. Pinto-Juma \& M.W. Bruford (2014). Mitochondrial DNA and morphological variation in the sentinel earthworm species Lumbricus rubellus. European Journal of Soil Biology 64: 23-29. https://doi.org/10.1016/j. ejsobi.2014.07.002

Edwards, C.A. (2004). Earthworm Ecology. CRC Press, Boca Raton, 456pp. https://doi.org/10.1201/9781420039719

Enckell, P.H., M. Niklasson, B. Stille \& P. Douwes (1986). Insulation and isolation: factors influencing the genetic variation in Lumbricus rubellus Hoffm. (Lumbricidae) in the Faroe Islands. Hereditas 104(2): 263-271. https://doi.org/10.1111/j.1601-5223.1986.tb00540.x

Erséus, C. (2005). Phylogeny of oligochaetous Clitellata. Hydrobiologia 535(1): 357-372.

Escudero, G.J., J. Lagerlöf, C.M. Debat \& P.C. Alberto (2019). Identification of earthworm species in Uruguay based on morphological and molecular methods. Agrociencia 23(1): 37-46. https://doi.org/10.31285/AGRO.23.1.12

Fernández, R., A. Almodóvar, M. Novo, M. Gutiérrez \& D.J.D. Cosín (2011). A vagrant clone in a peregrine species: phylogeography, high clonal diversity and geographical distribution in the earthworm Aporrectodea trapezoides (Dugès, 1828). Soil Biology 
and Biochemistry 43(10): 2085-2093. https://doi.org/10.1016/j soilbio.2011.06.007

Fernández, R., A. Almodóvar, M. Novo, B. Simancas \& D.J.D. Cosín (2012). Adding complexity to the complex: new insights into the phylogeny, diversification and origin of parthenogenesis in the Aporrectodea caliginosa species complex (Oligochaeta, Lumbricidae). Molecular Phylogenetics and Evolution 64(2): 368379. https://doi.org/10.1016/j.ympev.2012.04.011

Fernández, R., M. Novo, D.F. Marchán \& D.J.D. Cosín (2016). Diversification patterns in cosmopolitan earthworms: similar mode but different tempo. Molecular Phylogenetics and Evolution 94: 701-708. https://doi.org/10.1016/j.ympev.2015.07.017

Folino-Rorem, N.C., J.A. Darling \& C.A. D’Ausilio (2009). Genetic analysis reveals multiple cryptic invasive species of the hydrozoan genus Cordylophora. Biological Invasions 11(8): 1869-1882. https:// doi.org/10.1007/s10530-008-9365-4

Frelich, L.E., C.M. Hale, P.B. Reich, A.R. Holdsworth, S. Scheu, L. Heneghan \& P.J. Bohlen (2006). Earthworm invasion into previously earthworm-free temperate and boreal forests. Biological invasions 8: 1235-1245. https://doi.org/10.1007/978-1-4020-5429-7_5

Ganin, G.N. \& D.M. Atopkin (2018). Molecular differentiation of epigeic and anceic forms of Drawida ghilarovi Gates, 1969 (Moniligastridae, Clitellata) in the Russian Far East: Sequence data of two mitochondrial genes. European Journal of Soil Biology 86: 1-7. https://doi.org/10.1016/j.ejsobi.2018.02.004

Giska, I., P. Sechi \& W. Babik (2015). Deeply divergent sympatric mitochondrial lineages of the earthworm Lumbricus rubellus are not reproductively isolated. BMC Evolutionary Biology 15(1): 1-13. https://doi.org/10.1186/s12862-015-0488-9

Gregory, T.R. (2005). DNA barcoding does not compete with taxonomy. Nature 434(7037): 1067-1067. https://doi. org/10.1038/4341067b

Hebert, P.D., A. Cywinska, S.L. Ball \& J.R. Dewaard (2003). Biological identifications through DNA barcodes. Proceeding of Royal Society of London 270(1512): 313-321. https://doi.org/10.1098/ rspb.2002.2218

Hebert, P.D., M.Y. Stoeckle, T.S. Zemlak \& C.M. Francis (2004). Identification of birds through DNA barcodes. PLoS Biology 2(10): 312. https://doi.org/10.1371/journal.pbio.0020312

Heethoff, M., K. Etzold \& S. Scheu (2004). Mitochondrial COI sequences indicate that the parthenogenetic earthworm Octolasion tyrtaeum (Savigny 1826) constitutes of two lineages differing in body size and genotype. Pedobiologia 48(1): 9-13. https://doi.org/10.1016/j. pedobi.2003.04.001

Hendrix, P.F. \& P.J. Bohlen (2002). Exotic earthworm invasions in North America: ecological and policy implications. Bioscience 52(9): 801811. https://doi.org/10.1641/0006-3568(2002)052[0801:EEIINA]2. $0 . \mathrm{CO} ; 2$

Hogg, I.D., M.L. Stevens, K.E. Schnabel \& M. Chapman (2006). Deeply divergent lineages of the widespread New Zealand amphipod Paracalliope fluviatilis revealed using allozyme and mitochondrial DNA analyses. Freshwater Biology 51(2): 236-248. https://doi. org/10.1111/j.1365-2427.2005.01491.x

Hong, Y. \& C. Csuzdi (2016). New data to the earthworm fauna of the Korean peninsula with redescription of Eisenia koreana (Zicsi) and remarks on the Eisenia nordenskioldi species group (Oligochaeta, Lumbricidae). Zoological Studies 55: 1-15. http://doi.org/10.6620/ ZS.2016.55-12

Huang, J., Q. Xu, Z.J. Sun, G.L. Tang \& Z.Y. Su (2007). Identifying earthworms through DNA barcodes. Pedobiologia 51(4): 301-309. https://doi.org/10.1016/j.pedobi.2007.05.003

Huhta, V. (1979). Effects of liming and deciduous litter on earthworm (Lumbricidae) populations of a apruce forest, with an inoculation experiment on Allobophora caliginosa. Pedobiologia 19: 340-345.

Hulme, P.E., D.B. Roy, T. Cunha \& T.B. Larsson (2009). A panEuropean inventory of alien species: rationale, implementation and implications for managing biological invasions, pp. 1-14. In: Dais, I.E. (ed.). Handbook of Alien Species in Europe. Springer, Netherlands. https://doi.org/10.1007/978-1-4020-8280-1_1
James, S.W., D. Porco, T. Decaëns, B. Richard, R. Rougerie \& C. Erséus (2010). DNA barcoding reveals cryptic diversity in Lumbricus terrestris L., 1758 (Clitellata): resurrection of L. herculeus (Savigny, 1826). PLoS One 5(12): e15629. https://doi.org/10.1371/journal. pone.0015629

Jamieson, B.G. (1988). On the phylogeny and higher classification of the Oligochaeta. Cladistics 4(4): 367-401. https://doi. org/10.1111/j.1096-0031.1988.tb00520.x

Jamieson, B.G., S. Tillier, A. Tillier, J.L. Justine, E. Ling, S. James, K. McDonald \& A.F. Hugall (2002). Phylogeny of the Megascolecidae and Crassiclitellata (Annelida, Oligochaeta): combined versus partitioned analysis using nuclear (28S) and mitochondrial (12S, 16S) rDNA. Zoosystema 24(4): 707-734. http://doi.org/10.5281/ zenodo. 4524860

Jeratthitikul, E., U. Bantaowong \& S. Panha (2017). DNA barcoding of the Thai species of terrestrial earthworms in the genera Amynthas and Metaphire (Haplotaxida: Megascolecidae). European Journal of Soil Biology 81: 39-47. https://doi.org/10.1016/j.ejsobi.2017.06.004

Jirapatrasilp, P., P. Prasankok, C. Sutcharit, R. Chanabun \& S. Panha (2016). Two new Cambodian semi-aquatic earthworms in the genus Glyphidrilus Horst, 1889 (Oligochaeta, Almidae), based on morphological and molecular data. Zootaxa 4189(3): 543-558. https://doi.org/10.11646/zootaxa.4189.3.5

Kautenburger, R. (2006). Genetic structure among earthworms (Lumbricus terrestris L.) from different sampling sites in western Germany based on random amplified polymorphic DNA. Pedobiologia 50(3): 257-266. https://doi.org/10.1016/j. pedobi.2006.02.005

King, R.A., A.L. Tibble \& W.O. Symondson (2008). Opening a can of worms: unprecedented sympatric cryptic diversity within British lumbricid earthworms. Molecular Ecology 17(21): 4684-4698. https://doi.org/10.1111/j.1365-294X.2008.03931.x

Klarica, J., A. Kloss-Brandstätter, M. Traugott \& A. Juen (2012). Comparing four mitochondrial genes in earthworms-Implications for identification, phylogenetics, and discovery of cryptic species. Soil Biology and Biochemistry 45: 23-30. https://doi.org/10.1016/j. soilbio.2011.09.018

Kumari, N. \& S.K. Thakur (2014). Randomly amplified polymorphic DNA-a brief review. American Journal of Animal and Veterinary Sciences 9(1): 6-13. http://doi.org/10.3844/ajavsp.2014.6.13

Lalthanzara, H., R. Lalfelpuii, C. Zothansanga, M. Vabeiryureilai, N.S. Kumar \& G. Gurusubramanium (2018). Oligochaete taxonomy-The rise of earthworm DNA barcode in India. Science Vision 18(1): 1-10. https://doi.org/10.33493/scivis.18.01.01

Lalthanzara, H., C. Zothansanga, M. Lalchhanhima, N.S. Kumar, J. Ngukir, A. Kimsing \& M. Vabeiryureilai (2020). Diversity and New Records of Earthworms in Arunachal Pradesh, Northeast India. Journal of Environmental Biology 41(4): 874-883. http://doi. org/10.22438/jeb/4(SI)/MS_1921

Lavelle, P., L. Brussaard \& P. Hendrix (Eds.) (1999). Earthworm Management in Tropical Agroecosystems. CABI Publishing, New York, $300 \mathrm{pp}$.

Liu, Y., S.V. Fend, S. Martinsson, X. Luo, A. Ohtaka \& C. Erséus (2017). Multi-locus phylogenetic analysis of the genus Limnodrilus (Annelida: Clitellata: Naididae). Molecular Phylogenetics and Evolution 112: 244-257. https://doi.org/10.1016/j.ympev.2017.04.019

Lone, A.R., N. Tiwari, S.S. Thakur, O. Pearlson, T. Pavlíček \& S. Yadav (2020). Exploration of four new Kanchuria sp. of earthworms (Oligochaeta: Megascolecidae) from the North Eastern Region of India using DNA bar-coding approach. Journal of AsiaPacific Biodiversity 13(2): 268-281. https://doi.org/10.1016/j. japb.2020.02.004

Maekawa, K., M. Kon, K. Araya \& T. Matsumoto (2001). Phylogeny and biogeography of wood-feeding cockroaches, genus Salganea Stål (Blaberidae: Panesthiinae), in southeast Asia based on mitochondrial DNA sequences. Journal of Molecular Evolution 53(6): 651-659. https://doi.org/10.1007/s002390010252

Marchán, D.F., R. Fernández, M. Novo \& D.J.D. Cosín (2014). New light into the hormogastrid riddle: morphological and molecular 
description of Hormogaster joseantonioi sp. n. (Annelida, Clitellata, Hormogastridae). ZooKeys 414: 1-17. http://doi.org/10.3897/ zookeys.414.7665

Marchán, D.F., R. Fernández, I. de Sosa, D.J.D. Cosin \& M. Novo (2017). Pinpointing cryptic borders: fine-scale phylogeography and genetic landscape analysis of the Hormogaster elisae complex (Oligochaeta, Hormogastridae). Molecular Phylogenetics and Evolution 112: 185193. https://doi.org/10.1016/j.ympev.2017.05.005

Martin, P., I. Kaygorodova, D.Y. Sherbakov \& E. Verheyen (2000) Rapidly evolving lineages impede the resolution of phylogenetic relationships among Clitellata (Annelida). Molecular Phylogenetics and Evolution 15(3): 355-368. https://doi.org/10.1006/ mpev.1999.0764

Martinsson, S. \& C. Erséus (2014). Cryptic diversity in the wellstudied terrestrial worm Cognettia sphagnetorum (Clitellata: Enchytraeidae). Pedobiologia 57(1): 27-35. https://doi. org/10.1016/j.pedobi.2013.09.006

Martinsson, S. \& E. Erséus (2017). Cryptic speciation and limited hybridization within Lumbricus earthworms (Clitellata: Lumbricidae). Molecular Phylogenetics and Evolution 106: 18-27. https://doi. org/10.1016/j.ympev.2016.09.011

McHugh, D. (2001). Molecular phylogenetic analyses indicate a rapid radiation of polychaete annelids. American Zoologist 41: 1520-1521

Michaelsen, W. (1900). Das Tierreich 10: Vermes, Oligochaeta. Friedländer and Sohn, Berlin, 575 pp.

Minamiya, Y., J. Yokoyama \& T. Fukuda (2009). A phylogeographic study of the Japanese earthworm, Metaphire sieboldi (Horst, 1883) (Oligochaeta: Megascolecidae): Inferences from mitochondrial DNA sequences. European Journal of Soil Biology 45(5-6): 423-430. https://doi.org/10.1016/j.ejsobi.2009.06.004

Novo, M., A. Almodóvar \& D.J. Díaz-Cosín (2009). High genetic divergence of hormogastrid earthworms (Annelida, Oligochaeta) in the central Iberian Peninsula: evolutionary and demographic implications. Zoologica Scripta 38(5): 537-552. https://doi. org/10.1111/j.1463-6409.2009.00389.x

Novo, M., A. Almodóvar, R. Fernández, D. Trigo \& D.J.D. Cosín (2010). Cryptic speciation of hormogastrid earthworms revealed by mitochondrial and nuclear data. Molecular Phylogenetics and Evolution 56(1): 507-512. https://doi.org/10.1016/j. ympev.2010.04.010

Novo, M., A. Almodóvar, R. Fernández, G. Giribet \& D.J.D. Cosín (2011). Understanding the biogeography of a group of earthworms in the Mediterranean basin. The phylogenetic puzzle of Hormogastridae (Clitellata: oligochaeta). Molecular Phylogenetics and Evolution 61(1): 125-135. https://doi.org/10.1016/j.ympev.2011.05.018

Novo, M., R. Fernández, D.F. Marchan, D. Trigo, D.J.D. Cosin \& G. Giribet (2015a). Unearthing the historical biogeography of Mediterranean earthworms (Annelida: hormogastridae). Journal of Biogeography 42(4): 751-762. https://doi.org/10.1111/jbi.12447

Novo, M., L. Cunha, A. Maceda-Veiga, J.A. Talavera, M.E. Hodson, D. Spurgeon, M.W. Bruford, A.J. Morgan \& P. Kille (2015b). Multiple introductions and environmental factors affecting the establishment of invasive species on a volcanic island. Soil Biology and Biochemistry 85: 89-100. https://doi.org/10.1016/j.soilbio.2015.02.031

O'Grady, P.M. \& R. DeSalle (2018). Phylogeny of the genus Drosophila. Genetics 209(1): 1-25. https://doi.org/10.1534/ genetics.117.300583

Otomo, P.V., B.J.V. Vuuren \& S.A. Reinecke (2009). Usefulness of DNA barcoding in ecotoxicological investigations: resolving taxonomic uncertainties using Eisenia as an example. Bulletin of Environmental Contamination and Toxicology 82(3): 261-264. https://doi. org/10.1007/s00128-008-9585-4

Pejchar, L. \& H.A. Mooney (2009). Invasive species, ecosystem services and human well-being. Trends in Ecology and Evolution 24(9): 497504. https://doi.org/10.1016/j.tree.2009.03.016

Pérez-Losada, M., J. Eiroa, S. Mato \& J. Domínguez (2005). Phylogenetic species delimitation of the earthworms Eisenia fetida (Savigny, 1826) and Eisenia Andrei Bouche', 1972 (Oligochaeta, Lumbricidae) based on mitochondrial and nuclear DNA sequence. Pedobiologia
49(4): 317-324. https://doi.org/10.1016/j.pedobi.2005.02.004

Pérez-Losada, M., M. Ricoy, J.C. Marshall \& J. Domínguez (2009). Phylogenetic assessment of the earthworm Aporrectodea caliginosa species complex (Oligochaeta: Lumbricidae) based on mitochondrial and nuclear DNA sequences. Molecular Phylogenetics and Evolution 52(2): 293-302. https://doi.org/10.1016/j.ympev.2009.04.003

Pop, A.A., M. Wink \& V.V. Pop (2003). Use of 18S, 16S rDNA and cytochrome c oxidase sequences in earthworm taxonomy (Oligochaeta, Lumbricidae): The 7th international symposium on earthworm ecology Cardiff. Wales. Pedobiologia 47(5-6): 428-433. https://doi.org/10.1078/0031-4056-00208

Pop, A.A. \& M. Wink (2004). Molecular taxonomy and phylogeny of earthworms (Oligochaeta, Lumbricidae): 16S rDNA and COI gene corroborate numerical taxonomy in the genus Octodrilus, Omode, 1956, pp. 347-360. In: Moreno A.G. \& S. Borges (eds.). Advances in Taxonomy of Closing Worms. Advances in Earthworm Taxonomy. Editorial Complutense, Madrid.

Pop, A.A., G. Cech, M. Wink, C. Csuzdi \& V.V. Pop (2007). Application of $16 \mathrm{~S}, 18 \mathrm{~S}$ rDNA and COI sequences in the molecular systematics of the earthworm family Lumbricidae (Annelida, Oligochaeta). European Journal of Soil Biology 43: S43-S52. https://doi.org/10.1016/j. ejsobi.2007.08.007

Pop, A.A., C. Csuzdi, M. Wink \& V.V. Pop (2008). Molecular taxonomy and phylogeny of the genera Octolasion Örley, 1885, Octodrilus Omodeo, 1956 and Octodriloides Zicsi, 1986 (Oligochaeta, Lumbricidae) based on nucleotide sequences of mitochondrial $16 \mathrm{~S}$ rDNA and COI genes, pp. 109-128. In: Pavlicek, T. \& P. Cardet (eds.). Advances in Earthworm Taxonomy III (Annelida: Oligochaeta). Nicosia, Cyprus.

Porco, D., T. Decaëns, L. Deharveng, S.W. James, D. Skarżyński, C. Erséus, K.R. Butt, B. Richard \& P.D. Hebert (2013). Biological invasions in soil: DNA barcoding as a monitoring tool in a multiple taxa survey targeting European earthworms and springtails in North America. Biological Invasions 15(4): 899-910. https://doi. org/10.1007/s10530-012-0338-2

Proudlove, G. \& P.J. Wood (2003). The blind leading the blind: cryptic subterranean species and DNA taxonomy. Trends in Ecology and Evolution 6(18): 272-273. http://doi.org/10.1016/S01695347(03)00095-8

Qiu, J. (2015). A global synthesis of the effects of biological invasions on greenhouse gas emissions. Global Ecology and Biogeography 24(11): 1351-1362. https://doi.org/10.1111/geb.12360

Richard, B., T. Decaëns, R. Rougerie, S.W. James, D. Porco \& P.D.N. Hebert (2010). Re-integrating earthworm juveniles into soil biodiversity studies: species identification through DNA barcoding. Molecular Ecology Resources 10(4): 606-614. https://doi. org/10.1111/j.1755-0998.2009.02822.x

Römbke, J., M. Aira, T. Backeljau, K. Breugelmans, J. Domínguez, E. Funke, N. Graf, M. Hajibabaei, M. Pérez-Losada, P.G. Porto \& R.M. Schmelz (2016). DNA barcoding of earthworms (Eisenia fetida/andrei complex) from 28 ecotoxicological test laboratories. Applied Soil Ecology 104: 3-11. https://doi.org/10.1016/j. apsoil.2015.02.010

Rougerie, R., T. Decaëns, L. Deharveng, D. Porco, S.W. James, C.H. Chang, B. Richard, M. Potapov, Y. Suhardjono \& P.D.N. Hebert (2009). DNA barcodes for soil animal taxonomy. Pesquisa Agropecuária Brasileira 44(8): 789-802. https://doi.org/10.1590/ S0100-204X2009000800002

Sakai, A.K., F.W. Allendorf, J.S. Holt, D.M. Lodge, J. Molofsky, K.A. With, S. Baughman, R.J. Cabin, J.E. Cohen, N.C. Ellstrand \& D.E. McCauley (2001). The population biology of invasive species. Annual Review of Ecology and Systematics 32(1): 305-332. https://doi.org/10.1146/ annurev.ecolsys.32.081501.114037

Schult, N., K. Pittenger, S. Davalos \& D. McHugh (2016). Phylogeographic analysis of invasive Asian earthworms (Amynthas) in the northeast United States. Invertebrate Biology 135(4): 314327.

Seesamut, T., C. Sutcharit, P. Jirapatrasilp, R. Chanabun \& S. Panha (2018). Morphological and molecular evidence reveal a new species 
of the earthworm genus Pontodrilus Perrier, 1874 (Clitellata, Megascolecidae) from Thailand and Peninsular Malaysia. Zootaxa 4496(1): 218-237. https://doi.org/10.11646/zootaxa.4496.1.18

Shekhovtsov, S.V., E.V. Golovanova \& S.E. Peltek (2013). Cryptic diversity within the Nordenskiold's earthworm, Eisenia nordenskiold subsp. nordenskioldi (Lumbricidae, Annelida). European Journal of Soil Biology 58: 13-18. https://doi.org/10.1016/j.ejsobi.2013.05.004

Shekhovtsov, S.V., E.V. Golovanova \& S.E. Peltek (2014). Invasive lumbricid earthworms of Kamchatka (Oligochaeta). Zoological Studies 53(1): 1-15. https://doi.org/10.1186/s40555-014-0052-0

Shekhovtsov, S.V., D.I. Berman, N.E. Bazarova, N.A. Bulakhova, D. Porco \& S.E. Peltek (2016a). Cryptic genetic lineages in Eisenia nordenskioldi pallida (Oligochaeta, Lumbricidae). European Journal of Soil Biology 75: 151-156. https://doi.org/10.1016/j. ejsobi.2016.06.004

Shekhovtsov, S.V., E.V. Golovanova \& S.E. Peltek (2016b). Mitochondrial DNA variation in Eisenia n. nordenskioldi (Lumbricidae) in Europe and Southern Urals. Mitochondrial DNA 27(6): 4643-4645. https:// doi.org/10.3109/19401736.2015.1101594

Shekhovtsov, S.V., Golovanova, E.V \& S.E. Peltek (2016c). Different dispersal histories of lineages of the earthworm Aporrectodea caliginosa (Lumbricidae, Annelida) in the Palearctic. Biological Invasions 18(3): 751-761. http://doi.org/10.1007/s10530-0151045-6

Shekhovtsov, S.V., D.I. Berman, N.A. Bulakhova, O.L. Makarova \& S.E. Peltek (2018a). Phylogeography of earthworms from high latitudes of Eurasia. Acta Zoologica Academiae Scientiarum Hungaricae 64(4): 369-382. http://doi.org/10.17109/AZH.64.4.369.2018

Shekhovtsov, S.V., D.I. Berman, N.A Bulakhova, N.N. Vinokurov \& S.E. Peltek (2018b). Phylogeography of Eisenia nordenskioldi nordenskioldi (Lumbricidae, Oligochaeta) from the north of Asia. Polar Biology 41(2): 237-247. https://doi.org/10.1007/s00300-017-2184-2

Siddall, M.E., K. Apakupakul, E.M. Burreson, K.A. Coates, C. Erséus, S.R. Gelder, M. Källersjö \& H. Trapido-Rosenthal (2001). Validating Livanow: molecular data agree that leeches, Branchiobdellidans and Acanthobdella peledina form a monophyletic group of Oligochaetes. Molecular Biology and Evolution 21(3): 346-351. https://doi. org/10.1006/mpev.2001.1021

Stange, M., R.D. Barrett \& A.P. Hendry (2020). The importance of genomic variation for biodiversity, ecosystems and people. Nature Reviews Genetics 1-17. https://doi.org/10.1038/s41576-02000288-7

Su, Z.H., Y. Imura \& S. Osawa (2001). Evolutionary discontinuity of the carabine ground beetles. Journal of Molecular Evolution 53(4-5) 517-529. https://doi.org/10.1007/s002390010242

Szederjesi, T., V.v. Pop, T. Pavlíček, O. MÁrton, V. Krízsik \& C. Csuzdi (2018). Integrated taxonomy reveals multiple species in the Dendrobaena byblica (Rosa, 1893) complex (Oligochaeta: Lumbricidae). Zoological Journal of the Linnaean Society 182(3): 500-516. https://doi.org/10.1093/zoolinnean/zlx049

Terhivuo, J. \& A. Saura (1993). Genic and morphological variation of the parthenogenetic earthworm Aporrectodea rosea in southern Finland (Oligochaeta, Lumbricidae). Annales zoologici fennici 30(12): 215-224. http://www.jstor.org/stable/23735649

Terhivuo, J. \& A. Saura (1997). Island biogeography of North European parthenogenetic Lumbricidae: I. Clone pool affinities and morphometric differentiation of Åland populations. Ecography 20(2): 185-196. https://doi.org/10.1111/j.1600-0587.1997.tb00361.x
Thakur, S.S., A.R. Lone, N. Tiwari \& S. Yadav (2020). Exploring new records of Eutyphoeus sp.(haplotaxida: Octochaetidae) from garo hills, Meghalaya, North Eastern state of India with use of DNA barcodes. Mitochondrial DNA Part A 31(7): 265-272. https://doi.or g/10.1080/24701394.2020.1781834

Tiwari, N., A.R. Lone, S.S. Thakur \& S. Yadav (2020). Interrogation of earthworm (Clitellata: Haplotaxida) taxonomy and the DNA sequence database. Journal of Asia-Pacific Biodiversity 14(1): 4052. https://doi.org/10.1016/j.japb.2020.09.015

Torres-Leguizamon, M., J. Mathieu, T. Decaens \& L. Dupont (2014). Genetic structure of earthworm populations at a regional scale: inferences from mitochondrial and microsatellite molecular markers in Aporrectodea icterica (Savigny 1826). PLoS One 9(7): e101597. https://doi.org/10.1371/journal.pone.0101597

Tsutsui, N.D., A.V. Suarez, D.A. Holway \& T.J. Case (2000). Reduced genetic variation and the success of an invasive species. Proceedings of the National Academy of Sciences 97(11): 5948-5953. https://doi. org/10.1073/pnas.100110397

Vabeiryureilai, M., C. Zothansanga, M. Lalchhanhima, N.S. Kumar \& H. Lalthanzara (2020). Study on the Amynthas (Kinberg, 1867) earthworm (Megascolecidae: Oligochaeta) diversity through DNA barcoding from Northeast India. Journal of Environmental Biology 41(4): 867-873. http://doi.org/10.22438/jeb/4(SI)/ MS 1919

Vilà, M., J.L. Espinar, M. Hejda, P.E. Hulme, V. Jarošík, J.L. Maron, J. Pergl, U. Schaffner, Y. Sun \& P. Pyšek (2011). Ecological impacts of invasive alien plants: a meta-analysis of their effects on species, communities and ecosystems. Ecology Letters 14(7): 702-708. https://doi.org/10.1111/j.1461-0248.2011.01628.x

Vivien, R., S. Wyler, M. Lafont \& J. Pawlowski (2015). Molecular barcoding of aquatic oligochaetes: Implications for biomonitoring. PLoS One 10(4): e0125485. https://doi.org/10.1371/journal. pone. 0125485

Voua Otomo, P., M.S. Maboeta \& C. Bezuidenhout (2013). Inadequate taxonomy and highly divergent $\mathrm{CO}$ haplotypes in laboratory and field populations of earthworms used in ecotoxicology: a case study. African Zoology 48(2): 290-297. https://hdl.handle.net/10520/ EJC145793

Wishart, M.J. \& J.M. Hughes (2003). Genetic population structure of the net-winged midge, Elporia barnardi (Diptera: Blephariceridae) in streams of the southwestern Cape, South Africa. Implications for dispersal. Freshwater Biology 48(1): 28-38. https://doi. org/10.1046/j.1365-2427.2003.00958.x

Yassin, A., P. Capy, L. Madi-Ravazzi, D. Ogereau \& J.R. David (2008). DNA barcode discovers two cryptic species and two geographical radiations in the invasive Drosophilid zaprionus indianus. Molecular Ecology Resources 8(3): 491-501. https://doi.org/10.1111/j.14718286.2007.02020.x

Zhang, L., P. Sechi, M. Yuan, J. Jiang, Y. Dong \& J. Qiu (2016). Fifteen new earthworm mitogenomes shed new light on phylogeny within the Pheretima complex. Scientific Reports 6(1): 1-11. https://doi. org/10.1038/srep20096

Zhao, Q., D. Cluzeau, J.B. Jiang, E.J. Petit, C. Briard, J. Sun, A. Prinzing \& J.P. Qiu (2015). Molecular Phylogeny of Pheretimoid Earthworms (Haplotaxina: Megascolecidae) Based on Mitochondrial DNA in Hainan Island, China. Molecular Biology 4(4): 1-16. http://doi. org/10.4172/2168-9547.1000138 
Dr. Albert G. Orr, Griffith University, Nathan, Australia

Dr. Sameer Padhye, Katholieke Universiteit Leuven, Belgium

Dr. Nancy van der Poorten, Toronto, Canada

Dr. Kareen Schnabel, NIWA, Wellington, New Zealand

Dr. R.M. Sharma, (Retd.) Scientist, Zoological Survey of India, Pune, India

Dr. Manju Siliwal, WILD, Coimbatore, Tamil Nadu, India

Dr. G.P. Sinha, Botanical Survey of India, Allahabad, India

Dr. K.A. Subramanian, Zoological Survey of India, New Alipore, Kolkata, India

Dr. P.M. Sureshan, Zoological Survey of India, Kozhikode, Kerala, India

Dr. R. Varatharajan, Manipur University, Imphal, Manipur, India

Dr. Eduard Vives, Museu de Ciències Naturals de Barcelona, Terrassa, Spain

Dr. James Young, Hong Kong Lepidopterists' Society, Hong Kong

Dr. R. Sundararaj, Institute of Wood Science \& Technology, Bengaluru, India

Dr. M. Nithyanandan, Environmental Department, La Ala Al Kuwait Real Estate. Co. K.S.C., Kuwait

Dr. Himender Bharti, Punjabi University, Punjab, India

Mr. Purnendu Roy, London, UK

Dr. Saito Motoki, The Butterfly Society of Japan, Tokyo, Japan

Dr. Sanjay Sondhi, TITLI TRUST, Kalpavriksh, Dehradun, India

Dr. Nguyen Thi Phuong Lien, Vietnam Academy of Science and Technology, Hanoi, Vietnam

Dr. Nitin Kulkarni, Tropical Research Institute, Jabalpur, India

Dr. Robin Wen Jiang Ngiam, National Parks Board, Singapore

Dr. Lional Monod, Natural History Museum of Geneva, Genève, Switzerland.

Dr. Asheesh Shivam, Nehru Gram Bharti University, Allahabad, India

Dr. Rosana Moreira da Rocha, Universidade Federal do Paraná, Curitiba, Brasil

Dr. Kurt R. Arnold, North Dakota State University, Saxony, Germany

Dr. James M. Carpenter, American Museum of Natural History, New York, USA

Dr. David M. Claborn, Missouri State University, Springfield, USA

Dr. Kareen Schnabel, Marine Biologist, Wellington, New Zealand

Dr. Amazonas Chagas Júnior, Universidade Federal de Mato Grosso, Cuiabá, Brasil

Mr. Monsoon Jyoti Gogoi, Assam University, Silchar, Assam, India

Dr. Heo Chong Chin, Universiti Teknologi MARA (UiTM), Selangor, Malaysia

Dr. R.J. Shiel, University of Adelaide, SA 5005, Australia

Dr. Siddharth Kulkarni, The George Washington University, Washington, USA

Dr. Priyadarsanan Dharma Rajan, ATREE, Bengaluru, India

Dr. Phil Alderslade, CSIRO Marine And Atmospheric Research, Hobart, Australia

Dr. John E.N. Veron, Coral Reef Research, Townsville, Australia

Dr. Daniel Whitmore, State Museum of Natural History Stuttgart, Rosenstein, Germany.

Dr. Yu-Feng Hsu, National Taiwan Normal University, Taipei City, Taiwan

Dr. Keith V. Wolfe, Antioch, California, USA

Dr. Siddharth Kulkarni, The Hormiga Lab, The George Washington University, Washington,

D.C., USA

Dr. Tomas Ditrich, Faculty of Education, University of South Bohemia in Ceske

Budejovice, Czech Republic

Dr. Mihaly Foldvari, Natural History Museum, University of Oslo, Norway

Dr. V.P. Uniyal, Wildlife Institute of India, Dehradun, Uttarakhand 248001, India

Dr. John T.D. Caleb, Zoological Survey of India, Kolkata, West Bengal, India

Dr. Priyadarsanan Dharma Rajan, Ashoka Trust for Research in Ecology and the Environment (ATREE), Royal Enclave, Bangalore, Karnataka, India

\section{Fishes}

Dr. Neelesh Dahanukar, IISER, Pune, Maharashtra, India

Dr. Topiltzin Contreras MacBeath, Universidad Autónoma del estado de Morelos, México

Dr. Heok Hee Ng, National University of Singapore, Science Drive, Singapore

Dr. Rajeev Raghavan, St. Albert's College, Kochi, Kerala, India

Dr. Robert D. Sluka, Chiltern Gateway Project, A Rocha UK, Southall, Middlesex, UK

Dr. E. Vivekanandan, Central Marine Fisheries Research Institute, Chennai, India

Dr. Davor Zanella, University of Zagreb, Zagreb, Croatia

Dr. A. Biju Kumar, University of Kerala, Thiruvananthapuram, Kerala, India

Dr. Akhilesh K.V., ICAR-Central Marine Fisheries Research Institute, Mumbai Research

Centre, Mumbai, Maharashtra, India

Dr. J.A. Johnson, Wildlife Institute of India, Dehradun, Uttarakhand, India

\section{Amphibians}

Dr. Sushil K. Dutta, Indian Institute of Science, Bengaluru, Karnataka, India

Dr. Annemarie Ohler, Muséum national d'Histoire naturelle, Paris, France

\section{Reptiles}

Dr. Gernot Vogel, Heidelberg, Germany

Dr. Raju Vyas, Vadodara, Gujarat, India

Dr. Pritpal S. Soorae, Environment Agency, Abu Dubai, UAE.

Prof. Dr. Wayne J. Fuller, Near East University, Mersin, Turkey

Prof. Chandrashekher U. Rivonker, Goa University, Taleigao Plateau, Goa. India

Dr. S.R. Ganesh, Chennai Snake Park, Chennai, Tamil Nadu, India

Dr. Himansu Sekhar Das, Terrestrial \& Marine Biodiversity, Abu Dhabi, UAE
Birds

Dr. Hem Sagar Baral, Charles Sturt University, NSW Australia

Dr. Chris Bowden, Royal Society for the Protection of Birds, Sandy, UK

Dr. Priya Davidar, Pondicherry University, Kalapet, Puducherry, India

Dr. J.W. Duckworth, IUCN SSC, Bath, UK

Dr. Rajah Jayapal, SACON, Coimbatore, Tamil Nadu, India

Dr. Rajiv S. Kalsi, M.L.N. College, Yamuna Nagar, Haryana, India

Dr. V. Santharam, Rishi Valley Education Centre, Chittoor Dt., Andhra Pradesh, India

Dr. S. Balachandran, Bombay Natural History Society, Mumbai, India

Mr. J. Praveen, Bengaluru, India

Dr. C. Srinivasulu, Osmania University, Hyderabad, India

Dr. K.S. Gopi Sundar, International Crane Foundation, Baraboo, USA

Dr. Gombobaatar Sundev, Professor of Ornithology, Ulaanbaatar, Mongolia

Prof. Reuven Yosef, International Birding \& Research Centre, Eilat, Israel

Dr. Taej Mundkur, Wetlands International, Wageningen, The Netherlands

Dr. Carol Inskipp, Bishop Auckland Co., Durham, UK

Dr. Tim Inskipp, Bishop Auckland Co, Durham, UK

Dr. V. Gokula, National College, Tiruchirappalli, Tamil Nadu, India

Dr. Arkady Lelej, Russian Academy of Sciences, Vladivostok, Russia

Dr. Simon Dowell, Science Director, Chester Zoo, UK

Dr. Mário Gabriel Santiago dos Santos, Universidade de Trás-os-Montes e Alto Douro,

Quinta de Prados, Vila Real, Portugal

Dr. Grant Connette, Smithsonian Institution, Royal, VA, USA

Dr. M. Zafar-ul Islam, Prince Saud Al Faisal Wildlife Research Center, Taif, Saudi Arabia

Mammals

Dr. Giovanni Amori, CNR - Institute of Ecosystem Studies, Rome, Italy

Dr. Anwaruddin Chowdhury, Guwahati, India

Dr. David Mallon, Zoological Society of London, UK

Dr. Shomita Mukherjee, SACON, Coimbatore, Tamil Nadu, India

Dr. Angie Appel, Wild Cat Network, Germany

Dr. P.O. Nameer, Kerala Agricultural University, Thrissur, Kerala, India

Dr. Ian Redmond, UNEP Convention on Migratory Species, Lansdown, UK

Dr. Heidi S. Riddle, Riddle's Elephant and Wildlife Sanctuary, Arkansas, USA

Dr. Karin Schwartz, George Mason University, Fairfax, Virginia.

Dr. Lala A.K. Singh, Bhubaneswar, Orissa, India

Dr. Mewa Singh, Mysore University, Mysore, India

Dr. Paul Racey, University of Exeter, Devon, UK

Dr. Honnavalli N. Kumara, SACON, Anaikatty P.O., Coimbatore, Tamil Nadu, India

Dr. Nishith Dharaiya, HNG University, Patan, Gujarat, India

Dr. Spartaco Gippoliti, Socio Onorario Società Italiana per la Storia della Fauna "Giuseppe

Altobello", Rome, Italy

Dr. Justus Joshua, Green Future Foundation, Tiruchirapalli, Tamil Nadu, India

Dr. H. Raghuram, The American College, Madurai, Tamil Nadu, India

Dr. Paul Bates, Harison Institute, Kent, UK

Dr. Jim Sanderson, Small Wild Cat Conservation Foundation, Hartford, USA

Dr. Dan Challender, University of Kent, Canterbury, UK

Dr. David Mallon, Manchester Metropolitan University, Derbyshire, UK

Dr. Brian L. Cypher, California State University-Stanislaus, Bakersfield, CA

Dr. S.S. Talmale, Zoological Survey of India, Pune, Maharashtra, India

Prof. Karan Bahadur Shah, Budhanilakantha Municipality, Kathmandu, Nepal

Dr. Susan Cheyne, Borneo Nature Foundation International, Palangkaraja, Indonesia

Dr. Hemanta Kafley, Wildlife Sciences, Tarleton State University, Texas, USA

\section{Other Disciplines}

Dr. Aniruddha Belsare, Columbia MO 65203, USA (Veterinary)

Dr. Mandar S. Paingankar, University of Pune, Pune, Maharashtra, India (Molecular)

Dr. Jack Tordoff, Critical Ecosystem Partnership Fund, Arlington, USA (Communities)

Dr. Ulrike Streicher, University of Oregon, Eugene, USA (Veterinary)

Dr. Hari Balasubramanian, EcoAdvisors, Nova Scotia, Canada (Communities)

Dr. Rayanna Hellem Santos Bezerra, Universidade Federal de Sergipe, São Cristóvão, Brazil

Dr. Jamie R. Wood, Landcare Research, Canterbury, New Zealand

Dr. Wendy Collinson-Jonker, Endangered Wildlife Trust, Gauteng, South Africa

Dr. Rajeshkumar G. Jani, Anand Agricultural University, Anand, Gujarat, India

Dr. O.N. Tiwari, Senior Scientist, ICAR-Indian Agricultural Research Institute (IARI), New

Delhi, India

Dr. L.D. Singla, Guru Angad Dev Veterinary and Animal Sciences University, Ludhiana, India

Dr. Rupika S. Rajakaruna, University of Peradeniya, Peradeniya, Sri Lanka

Dr. Bahar Baviskar, Wild-CER, Nagpur, Maharashtra 440013, India

Reviewers 2018-2020

Due to pausity of space, the list of reviewers for 2018-2020 is available online.
The opinions expressed by the authors do not reflect the views of the Journal of Threatened Taxa, Wildlife Information Liaison Development Society, Zoo Outreach Organization, or any of the partners. The journal, the publisher, the host, and the partners are not responsible for the accuracy of the political boundaries shown in the maps by the authors.

\footnotetext{
Print copies of the Journal are available at cost. Write to:

The Managing Editor, JoTT,

c/o Wildlife Information Liaison Development Society,

No. 12, Thiruvannamalai Nagar, Saravanampatti - Kalapatti Road,

Saravanampatti, Coimbatore, Tamil Nadu 641035, India

ravi@threatenedtaxa.org
} 


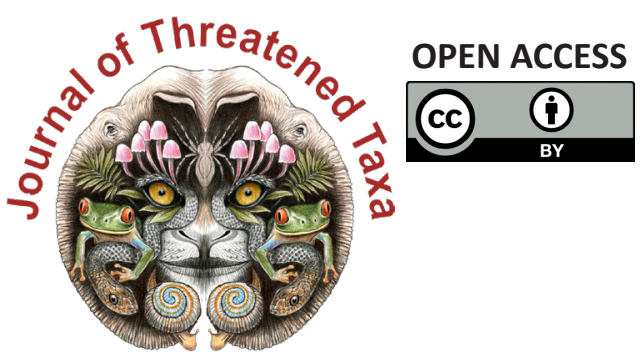

www.threatenedtaxa.org

The Journal of Threatened Taxa (JoTT) is dedicated to building evidence for conservation globally by publishing peer-reviewed articles online every month at a reasonably rapid rate at www.threatenedtaxa.org. All articles published in JoTT are registered under Creative Commons Attribution 4.0 International License unless otherwise mentioned. JoTT allows allows unrestricted use, reproduction, and distribution of articles in any medium by providing adequate credit to the author(s) and the source of publication.

\section{ISSN $0974-7907$ (Online) | ISSN $0974-7893$ (Print)}

\section{September 2021 | Vol. 13 | No. 11 | Pages: 19431-19674 Date of Publication: 26 September 2021 (Online \& Print) DOI: 10.11609/jott.2021.13.11.19431-19674}

Articles

Understanding human-flying fox interactions in the Agusan Marsh Wildlife Sanctuary as basis for conservation policy interventions

- Sherryl L. Paz \& Juan Carlos T. Gonzalez, Pp. 19431-19447

Argentinian odonates (dragonflies and damselflies): current and future distribution and discussion of their conservation

- A. Nava-Bolaños, D.E. Vrech, A.V. Peretti \& A. Córdoba-Aguilar, Pp. 19448-19465

\section{Communications}

The diel activity pattern of small carnivores of Western Ghats, India: a case study at Nelliampathies in Kerala, India

- Devika Sanghamithra \& P.O. Nameer, Pp. 19466-19474

Distribution and threats to Smooth-Coated Otters Lutrogale perspicillata (Mammalia: Carnivora: Mustelidae) in Shuklaphanta National Park, Nepal

- Gopi Krishna Joshi, Rajeev Joshi \& Bishow Poudel, Pp. 19475-19483

Wildlife hunting practices of the Santal and Oraon communities in Rajshahi, Bangladesh - Azizul Islam Barkat, Fahmida Tasnim Liza, Sumaiya Akter, Ashikur Rahman Shome \& M. Fazle Rabbe, Pp. 19484-19491

Ethnozoological use of primates in northeastern India

- Deborah Daolagupu, Nazimur Rahman Talukdar \& Parthankar Choudhury, Pp. 19492-19499

Factors influencing the flush response and flight initiation distance of three owl species in the Andaman Islands

- Shanmugavel Sureshmarimuthu, Santhanakrishnan Babu, Honnavalli Nagaraj Kumara \& Nagaraj Rajeshkumar, Pp. 19500-19508

Birds of Barandabhar Corridor Forest, Chitwan, Nepal

- Saneer Lamichhane, Babu Ram Lamichhane, Kapil Pokharel, Pramod Raj Regmi, Tulasi Prasad Dahal, Santosh Bhattarai, Chiranjibi Prasad Pokheral, Pabitra Gotame,

Trishna Rayamajhi, Ram Chandra Kandel \& Aashish Gurung, Pp. 19509-19526

On some additions to the amphibians of Gunung Inas Forest Reserve, Kedah,

Peninsular Malaysia

- Shahriza Shahrudin, Pp. 19527-19539

Reviews

A review of research on the distribution, ecology, behaviour, and conservation of the Slender Loris Loris lydekkerianus (Mammalia: Primates: Lorisidae) in India

- Mewa Singh, Mridula Singh, Honnavalli N. Kumara, Shanthala Kumar, Smitha D. Gnanaolivu \& Ramamoorthy Sasi, Pp. 19540-19552

Bivalves (Mollusca: Bivalvia) in Malaysian Borneo: status and threats

- Abdulla-Al-Asif, Hadi Hamli, Abu Hena Mustafa Kamal, Mohd Hanafi Idris, Geoffery James Gerusu, Johan Ismail \& Muyassar H. Abualreesh, Pp. 19553-19565

Disentangling earthworm taxonomic stumbling blocks using molecular markers

- Azhar Rashid Lone, Samrendra Singh Thakur, Nalini Tiwari, Olusola B. Sokefun \&

Shweta Yadav, Pp. 19566-19579

A reference of identification keys to plant-parasitic nematodes (Nematoda: Tylenchida) Tylenchomorpha)

- Reza Ghaderi, Manouchehr Hosseinvand \& Ali Eskandari, Pp. 19580-19602

Short Communications

Catalogue of herpetological specimens from Meghalaya, India at the Salim Ali Centre for Ornithology and Natural History

-S.R. Chandramouli, R.S. Naveen, S. Sureshmarimuthu, S. Babu, P.V. Karunakaran \&

Honnavalli N. Kumara, Pp. 19603-19610
A preliminary assessment of odonate diversity along the river Tirthan, Great Himalayan National Park Conservation Area, India with reference to the impact of climate change - Amar Paul Singh, Kritish De, Virendra Prasad Uniyal \& Sambandam Sathyakumar, Pp. 19611-19615

A checklist of orthopteran fauna (Insecta: Orthoptera) with some new records in the cold arid region of Ladakh, India

- M. Ali, M. Kamil Usmani, Hira Naz, Tajamul Hassan Baba \& Mohsin Ali, Pp. 19616-19625

New distribution records of two Begonias to the flora of Bhutan

- Phub Gyeltshen \& Sherab Jamtsho, Pp. 19626-19631

Rediscovery of Aponogeton lakhonensis A. Camus (Aponogetonaceae): a long-lost aquatic plant of India

- Debolina Dey, Shrirang Ramchandra Yadav \& Nilakshee Devi, Pp. 19632-19635

Glyphochloa acuminata (Hack.) Clayton var. laevis (Poaceae): a new variety from central Western Ghats of Karnataka, India

- H.U. Abhijit \& Y.L. Krishnamurthy, Pp. 19636-19639

A cytomorphological investigation of three species of the genus Sonchus L. (Asterales: Asteraceae) from Punjab, India

- M.C. Sidhu \& Rai Singh, Pp. 19640-19644

Dryopteris lunanensis (Dryopteridaceae) - an addition to the pteridophytic diversity of India

- Chhandam Chanda, Christopher Roy Fraser-Jenkins \& Vineet Kumar Rawat, Pp. 1964519648

Notes

First record of Spotted Linsang Prionodon pardicolor (Mammalia: Carnivora:

Prionodontidae) with photographic evidence in Meghalaya, India

- Papori Khatonier \& Adrian Wansaindor Lyngdoh, Pp. 19649-19651

First record of the Eastern Cat Snake Boiga gocool (Gray, 1835) (Squamata: Colubridae) from Tripura, India

- Sumit Nath, Biswajit Singh, Chiranjib Debnath \& Joydeb Majumder, Pp. 19652-19656

First record of the genus Tibetanja (Lepidoptera: Eupterotidae: Janinae) from India - Alka Vaidya \& H. Sankararaman, Pp. 19657-19659

Austroborus cordillerae (Mollusca: Gastropoda) from central Argentina: a rare, little-known land snail

- Sandra Gordillo, Pp. 19660-19662

Intestinal coccidiosis (Apicomplexa: Eimeriidae) in a Himalayan Griffon Vulture Gyps himalayensis

- Vimalraj Padayatchiar Govindan, Parag Madhukar Dhakate \& Ayush Uniyal, Pp. 1966319664

Two new additions to the orchid flora of Assam, India

- Sanswrang Basumatary, Sanjib Baruah \& Lal Ji Singh, Pp. 19665-19670

Wildlife art and illustration - combining black and white ink drawings with colour: some experiments in Auroville, India

- M. Eric Ramanujam \& Joss Brooks, Pp. 19671-19674
Publisher \& Host

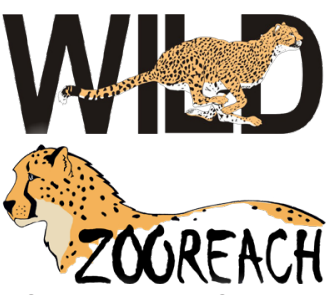

